\title{
Monetary Plurality in Economic Theory
}

\author{
Jérôme Blanc, Ludovic Desmedt, Laurent Le Maux, Jaime Marques-Pereira, Pepita \\ OULD AHMED, Bruno THERET*
}

\section{Introduction}

Contemporary monetary systems seem to be characterised by a unique currency for each country, though tending towards unification at a higher level. Monetary organisation ranked hierarchically by a central bank in a unified State would seem to be the norm. The organisation consists of a unit of account which is imposed on all economic agents within the sovereign territory, and of means of payment that are homogeneous and convertible into one another. This is framed by a regime of monetization that incorporates into a hierarchy topped by the central bank the commercial banks that issue money. Besides this, there seems to be a trend towards supra-national solutions within larger regions, leading to monetary unions of the type set up in 1999 by the European Union when it established the euro zone and subsequently gradually broadened it.

Nonetheless, a spectre is haunting contemporary monetary theory - the spectre of monetary plurality. The objective of this article is to identify this presence, going beyond traditional textbooks. It throws light on the way in which these theories are attracted towards both unicity and plurality, and more specifically by unification and diversification of money ${ }^{\mathbf{1}}$. It should also be noted, in this respect, that monetary theory has undergone considerable development since the 1970s and increasingly address monetary plurality issues. The rising theoretical tension between the poles of unity and plurality is forcing economists to pay attention to it. This is not merely anecdotal. Any survey of the diverse theories, whether mainstream or not, static or dynamic, holistic or individualistic, will reveal the surprising amount of attention devoted to the problem of monetary unicity and/or plurality. The problem may be raised deliberately or casually, directly or indirectly, seen as a result of equilibria or disequilibria, as a disorder to be reduced or an objective to be reached; the reasoning can be based on empirical observation, be hypothetico-deductive or be part of a normative theoretical construction aimed at transforming reality.

In order to accommodate the variety of thinking on the subject in a comprehensive set of economic theories, in this essay we propose to adopt a definition of monetary plurality that is multi-dimensional. We will study the plurality of means of payment or exchange and the plurality of units of account, standards of value or numeraires, within the areas considered by each approach. These areas do not necessarily have to be sovereign territories; they can be merely abstract spaces in which there are market relations between economic agents. We would like to make it clear that in a study of the plurality and unicity of money the reserve function cannot be equated with the other two functions: there are many potential instruments for preserving wealth that do not necessarily become money. The articulation between on the one hand a reserve of value in the form of private goods or financial assets, and on the other

\footnotetext{
* Jérôme Blanc (Université Lumière Lyon 2, Triangle), Ludovic Desmedt (Université de Bourgogne, LEG), Laurent Le Maux (Université Paris 8, LED), Jaime Marques-Pereira (Université de Picardie Jules Verne, CRIISEA), Pepita Ould Ahmed (IRD, Université Paris 1), Bruno Théret (CNRS, IRISSO).

${ }^{1}$ We will concentrate on specifically economic theories of money, excluding approaches that are socioeconomic, sociological, anthropological and historical, as their use of empirical observation and methods of theorisation and analytical generalisation are appreciably different from those of economics in general.
} 
money happens to be the point at which plurality impinges on the sphere of money.

Using this multi-dimensional definition, we envisage the various situations involving plurality or unicity of money. We base our presentation on two lines of thought that appear independent at first glance (Table 1).

The first of these lines of theorisation concerns a situation of general equilibrium, as opposed to theories giving pride of place to the forms of disequilibrium, evolutionary dynamics, and regime-crises. The general equilibrium theories usually see money as a financial asset and assume that it is neutral at least over the long term; theories of the second type, on the contrary, see money as a necessary condition for the development of trade, acknowledging that it influences the system of relative prices and consequently the dynamics of production. Thus money is presumed to be totally neutral ("super-neutral") in the New Classical Economics in the manner of Lucas $(1972,1995)$ and in the New Monetary Economics initiated by Black (1970) and Fama (1980). On the contrary, it is not neutral according to neo-Mengerian approaches and to those that are neo-Marxist, Chartalist and post-Keynesian. In an intermediate position we find the neoclassical synthesis and the monetarist approach that, though positioned within the analytical framework of general equilibrium, grants nonetheless that though in the long term money is neutral, in the short term it does play an active part.

The second line of thinking revolves round the relationship between economic theories and the problem of the unicity or plurality of money as a norm to be established. This relationship is often linked to the role assigned by the various approaches to finance. For example, the macroeconomics of the New Classical Economics school, in dealing with monetary "friction" within general equilibrium theory, maintains an approach that is largely "unitary", seeking to integrate it into its framework. In this respect it opposes the financial views of the New Monetary Economics, that are based on a pluralist notion of money, aiming moreover to ensure that it could be dispensed it with the world of reality. Similarly, neoMengerian economists, who develop a pluralist approach and see financing as the heart of the proper organisation of money, are opposed to the unitary approaches of Marxist, Chartalist and post-Keynesian economists, who feel that finance engenders perverse uses of money.

We will see nonetheless that unicity and plurality cannot be seen as total opposites. They have to be thought of together, in polarity; plurality can envelope unicity, and unicity can contain plurality. Thus, some theories are aimed at the promotion or theorisation of forms of monetary plurality, while remaining nonetheless influenced by the idea that the unicity of money remains the permanent horizon that guarantees the stability of the system and the efficacy of transactions. These pluralist approaches are thus "haunted" either by the need for a single unit of account (free banking theory) or by the selection of a stable unit of account (New Monetary Economics and the competitive fiat money model). Symmetrically, theories postulating or promoting the logical unicity of money are troubled by the idea of plurality, incorporating it either positively, as in the case of equilibria involving multiple currencies in some search models, or negatively, as in some Chartalist and Marxist views that treat as a pathology the circulation of several currencies within a single sovereign space.

Our study will thus conduct the reader from strongly pluralist approaches that are troubled by the idea of unicity (sections 2 and 3) to approaches that are strongly unitary, but haunted by the idea of plurality (sections 4 and 5). Section 2 will thus deal with the financial theories of money developed by New Monetary Economics (NME) (the Black-Fama-Hall model; the Yeager Greenfield System), positioned within the analytical horizon of general equilibrium. Next, Section 3 will examine the neo-Mengerian evolutionary pluralist approaches to money, which are situated outside the framework of general equilibrium (the 
free banking model, the competitive private fiat money model). Section 4 will focus on unitary macroeconomic approaches positioned within the analytical horizon of the general equilibrium theory (monetarism, and the overlapping generations, cash-in-advance, and search-theoretic models). Section 5 will deal with holistic unitary approaches reasoned in terms of disequilibrium, and those in evolutionary mode, such as Chartalism, postKeynesianism and post-Marxism.

Significantly, the theoretical dynamics of recent decades, opening up to the question of several moneys (New Monetary Economics, in particular), have moved back towards unitary approaches, seeking to analyse the role played by the emergence of financial derivatives in restructuring financial systems and stabilising a state of monetary plurality. The thesis propounded in this article is thus that since the 1970s monetary theory has undergone a deepseated renewal structured in particular by the tension between unicity and plurality in monetary matters. In conclusion, Section 6 will deal with this surprising oscillation between on one hand the postulate - or the display of the logical necessity - of a unique money, and alternatively the empirical conclusion that a unique money is inevitable, and on the other hand a logical construction of the necessity of plurality that nonetheless comes up against an exigency of fixed points.

The theories will not be examined for their intrinsic interest or for their specific audience, but insofar as they reveal the tension between monetary unicity and plurality. Our survey of contemporary theories will give rise to a typology of the forms of monetary unicity and plurality, framing a new reading of monetary theories.

Table 1 - Criteria of differentiation

\begin{tabular}{|l|l|l|}
\hline & Theories privileging plurality & Theories privileging unicity \\
\hline $\begin{array}{l}\text { In terms of general equilibrium: } \\
\text { neutrality of money }\end{array}$ & $\begin{array}{l}\text { New Monetary Economics (Section } \\
\text { 2) }\end{array}$ & $\begin{array}{l}\text { Monetary Walrasianism and beyond } \\
\text { (Section 4) }\end{array}$ \\
\hline $\begin{array}{l}\text { In terms of disequilibrium or } \\
\text { evolutionary models: non-neutrality } \\
\text { of money }\end{array}$ & $\begin{array}{l}\text { Neo-Mengerian approaches (Free } \\
\text { Banking, Hayek) (Section 3) }\end{array}$ & $\begin{array}{l}\text { Monetary Economy: post- } \\
\text { Keynesianism, neo-Chartalist and } \\
\text { Marxist approaches (Section 5) }\end{array}$ \\
\hline
\end{tabular}

\section{New Monetary Economics: from a plurality of means of payment to a repressed plurality of units of account}

\subsection{General characteristics}

New Monetary Economics (NME) is the name given by Hall (1982) to the current of neoclassical post-monetarist thought to which he belonged, and that argued in favour of a world without money. In this world monetary, banking, and financial systems would be completely deregulated. NME is in fact the view of money taken by neoclassical financial economics, which developed over the past forty years as part of the move towards the financialization of the market economy, money being seen as a by-product of market finance.

This school of thought advocates monetary plurality, considered to be a precondition for a social optimum when regulated solely by perfect competition between private banks as exclusive issuers of means of payment. NME sets itself the objective of imagining "perfectly competitive monetary economies" in which money does not prevent the law of value of the General Equilibrium Theory from taking full effect (Thompson, 1974). As a result, NME is 
radically critical not only of the Keynesian theory of liquidity preference, but also of the quantity theory of money. For NME, the quantity theory merely expresses the operation of historically contingent legal restrictions that prevent banks from issuing freely their own instruments of payment and exchange (Hall, 1982a).

Although the founding article by Black dates back to $1970^{2}$, the idea of doing away with base money as a government non-interest-bearing asset was only to gain acceptance as of 1980 thanks to articles published by Fama $(1980)^{3}$, Hall $(1981)^{4}$, and Greenfield and Yeager $(1983)^{5}$. This last article presents an alternative system of payment named by its authors "the BFH model", in reference to the previous papers of Black, Fama and Hall which it synthesises and attempts to surpass. However, following McCallum (2010) who thinks more appropriate to name it the "Yeager-Greenfield System", because of its specific nature, we below will refer to this "system" as YGS. The NME has been subsequently discussed in special issues of the Journal of Monetary Economics (1983) or the Cato Journal (1989, 2010). Cowen and Kroszner (1987, 1994) (henceforth CK) have also offered an historical perspective and overview of the whole current. According to CK, NME is "defined by a set of questions rather than by acceptance of a particular conclusion or method" (CK, 1994, 1). It comprises a rather broad array of notions that do not limit the issue of competition between private moneys to means of payment, but also include the question of a plurality of units of account. But whatever the monetary system devised, the big issue at stake is the mode of stabilisation of the overall level of prices (e.g. the way of anchoring the unit of account). This is in fact the main stumbling block recognised by NME. ${ }^{6}$

NME is based on an intimate combination of two theoretical hypotheses that distinguish it globally from the neo-Mengerian free banking school of thought (White, 1984a, 1987, 1989; O'Driscoll, 1985) (cf. section 3.2). In NME, given a context of total financial market deregulation, the theory of legal restrictions is intrinsically associated with a wager on the efficiency of monetary dualism, that is to say the effective separation of money between two media, a unit of account (imaginary money) and a means of payment (real money) (Scialom, 1995) ${ }^{7}$. According to NME, "money as we know it", i.e. the unique entity supporting all monetary functions, has become obsolete, as it is an inefficient, sub-optimal, and "fundamentally disequilibrating force" that should be dissolved by separating the functions of accounting and payment, each of which should be assigned to a specific support: "the unit of account might be purely abstract or take a real commodity form" and "exist separately from the media of payments" which "take the form of real assets claims" (CK, 1987, 569-570). Instead of issuing currency, we should rather establish on the one hand a unit

\footnotetext{
${ }^{2}$ Subsequently Black was to develop his monetary ideas in Black (1972, 1974, 1978 and 1981).

${ }^{3}$ Subsequently complemented by Fama (1983 and 1985).

${ }^{4}$ Subsequently complemented by Hall (1982a and b, 1983, 1992, 1997 and 2002).

${ }^{5}$ Complemented successively by Yeager (1983, 1985, 1989, 1992, 2001, 2010), Yeager \& Greenfield (1989), Woolsey (1992, 1993, 1994), and Greenfield, Woolsey \& Yeager (1995).

${ }^{6}$ The question of the pertinence and/or intrinsic viability of such systems of competitive private payment falls outside the scope of this article.

7 The NME “combines features of Wallace's 'Legal restrictions theory of money' with the possibility of separating the unit of account and medium of exchange functions of money (...)" (CK, 1987, 568). The theory of legal restrictions, initially developed by the New Classical (NC) school in Minnesota, led by Wallace and Sargent, will be dealt with in Section 4. The NME suggests an interpretation of this theory that was rejected by Wallace and his colleagues, who felt that certain legal restrictions on the issue of money and on banking practices were justified, in particular when considered from an international point of view (Kareken \& Wallace, 1978 ; Wallace, 1979).
} 
of account, and on the other financial production of monetary services.

But NME views also itself as evolutionary, a feature that brings it this time close to neo-Mengerian approaches: the invisible hand of competition, technological progress and market forces is leading humanity towards an economy without money that is already on the horizon. Thus, in their synthesis of the current, CK (1995) position NME explicitly within the framework of Mengerian evolutionism, which they propose to improve upon by correcting two points. In their view, on the one hand, the medium of account develops, both "logically and historically", prior to the emergence of a medium of exchange. And on the other hand, "their analysis does not end with the initial evolution of a single unified medium of account and exchange (Menger's money). The efficiencies occasioned by the use of generally accepted media of account, exchange, and settlement increase the liquidity of other assets, leading to further changes in financial institutions" (CK, 1994, 12). Three stages of financial evolution can thus be distinguished: an early phase (barter), an intermediate (Menger's money), and a late (competitive payments systems) stage. "Although an intermediate stage of financial evolution uses a dominant medium of account, considerable multiplicity prevails in the early and late stages" (ibid., 38). CK want to show that the separation of the medium of account from the media of exchange is not merely an abstract notion; for them it is the possible outcome of a trend that is part of the historical evolution of finance, which leads towards a broad diversification of interest-bearing financial assets that are increasingly susceptible to liquification, i.e. a process of their transformation into liquid money that allows them to be used as means of payment and exchange. These authors subsequently examine various "historical, actual, and hypothetical economies where financial innovation separate medium of account and exchange and generate multiple coexisting media of account, exchange, and settlement" (CK, 1994, 13-14). Therefore in order to study the range of competing monetary systems offered by NME it is necessary to distinguish weak plurality, limited to means of payment, from strong plurality, extended to units of account. Indeed, while these systems are most often thought of as not upsetting the unicity of the unit of account (BFH and YGS) (section 2.2), this unicity is nonetheless contested either implicitly (Hall) or explicitly (CK) (section 2.3).

\subsection{Weak plurality: competition in issuing means of payment in the work of Black, Fama and Hall, and in the Yeager-Greenfield System}

The basic institutional form advocated by NME in general and in particular in the YGS is a private bank that in offering monetary services is indistinguishable from money market mutual funds. Means of payment are shares of ownership in such a fund or, more broadly, in a portfolio of negotiable securities credited to a bank (which can thus also be a shareholder bank), the value of which is fixed by the financial markets from day to day.

The function of banking freed in this way from all legal monetary restrictions would no longer be to collect deposits in public currency on current accounts in the form of demand and time deposits. Banks would now produce interest-bearing assets which could be used as means of payment and exchange, by fractioning into shares the value of the capital assets they held. "Liquidity would be ensured by the ability of the common investment fund to sell off part of its negotiable portfolio. Solvability would be guaranteed by the parallel depreciation of the value of the portfolio and of the debts incurred as liabilities" (Scialom, 1995, 37).

This type of banking leads logically to the separation of the accounting and payment functions of money, as the overall value of the means of payment varies constantly according to that of the financial assets backing them. The unit of account can no longer be based on a means of payment, and has to be set in some other way, independently of the payment system. 
Whence the need to return to monetary dualism, which leads to a plurality of means of payment, leaving open the question of defining one or more units of account. Nonetheless, it is the unicity of the unit of account which has been upheld by most economists of the New Monetary school, and in particular those holding to the YGS model. In this case, the exchange value of the competing means of payment is given in an abstract unit of account fixed outside the payment system (a numeraire). (Greenfield \& Yeager, 1983). However, this does not imply, as is sometimes assumed, that the unit value of the means of payment is necessarily variable; as soon as the value of each share is equal to that of the unit of account, and it is the number of shares which varies from day to day with the value of the portfolio, the units of payment are fixed at par with the unit of account. Competition between banks and between their means of payment is therefore not supposed to affect the exchange rate of units of payment in the unit of account ${ }^{8}$, but rather the level of returns on demand accounts (these would depend on the quality of the portfolio management and the level of management fees), on prices invoiced on bookkeeping entries, accounting and checking services, and on the terms of credit.

The crucial question raised in a system of this sort, is that of the settlement of interbank debts, as there is no "base money - neither government-issued fiat money nor monetary stocks of particular commodities" (Greenfield \& Yeager, 1983, 308). In the YGS, under the auspices of their clearinghouses, banks are supposed to agree on what portfolio assets are acceptable for interbank debts' redemption. As there is only indirect convertibility of media of exchange into the unit of account that is backed against a medium of account made up of a very broad basket of goods (the value of which is supposed to reflect the overall level of prices), convertibility is guaranteed only in specific means of redemption ("such as gold or actively traded securities"). These guarantee assets can then be used for interbank settlements.

As noted by Scialom (1995), from this angle hierarchical principles are introduced that contradict the "overall project" of NME, such as it has been formulated in the framework of Walras' general equilibrium of pure and perfect competition between totally independent agents. This contradiction shows that NME is a set of hybrid theories that mix, in variable proportions, neoclassical and neo-mengerian ingredients.

In this respect, two positions can be distinguished that are polar opposites. One is represented by the YGS, and the other by the Hall's OFMS (Optimal Fiduciary Monetary Systems). Whereas Yeager is not far from being in favour of competitive private fiat money (cf. 3.1) (Yeager 1994, 1997 and 1998), Hall comes closer to the free banking supported by White (1984a and 1989), according to which government-issued money is hierarchically superior to private moneys (cf 3.2). This could explain Hall's explicit preference of a fiat money standard (Hall, 1992) and thus for a State that defines the unit of account and mechanic rules enabling its value to be stabilised automatically in terms of purchasing power (Hall, 1981). Hall thus sees as optimal an institutional arrangement according to which the government would issue reserve certificates that function not only as a medium of account, but also as a means of reserve that can serve as a means of interbank settlement (Hall, 1983).

\subsection{The issue of stabilising the unit of account: a common reference to the Compensated Dollar Plan}

Despite differentiated preferences as to the optimal type of standard, the NME is

\footnotetext{
${ }^{8}$ It is in this respect in particular that the competitive payments systems of the NME are distinguished from competitive private monies in the manner of Klein and Hayek.
} 
unified by a shared concern: automatic stabilisation of the purchasing power of the unit of account. This obsession reveals a recognition of the non-neutrality of money (the Austrian aspect of the approach) that is combined with a desire to neutralise it (the neo-classical aspect). For NME as a whole, instability of the overall level of prices is the main obstacle to making competitive payment systems really practicable (Black, 1981; Fama, 1983; Greenfield \& Yeager, 1983; Sumner, 1990; CK, 1994). And it is its main stumbling block since, as Yeager has recently written, on this question "further thought is (still) needed" (2010, 434). In fact, to solve the problem, many devices have been suggested.

For instance, after having considered a fiat money that would be backed only internationally against other national currencies within the framework of a "global monetarism" (Black, 1978), Black suggested in 1981 a "flexible commodity money standard" in the form of a "gold standard with double feedback and near zero reserves" (Black, 1981) that is "almost identical to Fisher's compensated dollar plan" (Sumner, 1990, 115). As to Fama, in 1980 he was envisaging a simple system with a commodity money of reference (a barrel of crude oil; a spaceship permit). Then in 1983, following Black (1970), he envisaged a State-issued money that would now play no more than a marginal role as means of payment but could continue to function as cash (it would be used only for small payments and payments by people who do not have access to the financial system and would no longer be base money), thus anchoring the unit of account outside the financial sphere. Nevertheless, he was considering that "either the monopoly fiduciary currency approach" that he preferred, "or the flexible commodity standards of Fisher (1920) and Black (1981) could be used to control the price level" (Fama 1983, 19).

Hall (1981) broadened the idea of a Compensated Dollar Plan (CDP) developed by Fisher (1920) ${ }^{9}$ to include a system of Government Reserve Certificates issued once for all (to prevent the Government from using them as an inflationary tax). Nonetheless, in 1982 he also suggested a more traditional system with a money of account anchored by direct convertibility in a limited commodity bundle of four items, ANCAP, selected with a view to medium-long term stability of their observed relative value in terms of the cost of living (Hall, 1982b, 1992). Hall claimed for this standard a rule, à la Fisher periodically adjusting the value of the dollar in ANCAP, in order to stabilise the purchasing power of the former by compensating price variations of the latter. In 1997, he will come to the idea of a CDP in which the unit of account for deferred contracts would be stabilised in terms of purchasing power by indexing it to a Unit of account (UOA) valid for short term contracts and payments, device giving place to a double unit of account (cf. below). This idea he took from the Chilean monetary system in which since 1976 there is an "imaginary" unit of account - the Unidad de Fomento (UF) - which is stabilised in terms of purchasing power by being indexed on the consumer price index expressed in peso (the "real" unit of account associated to the base currency used for current transactions). The stability of this system has been proven ever since the serious financial crisis Chile went through in 1981. It allowed the country to resist dollarization, and is presently routinely functioning. In Hall's view $(1997,2002)$, this is a typical case of CDP functioning with fiat moneys.

Hall thus advocates a system of fiat money with a dual unit of account: the nominal current account, based on the national currency and used for short-term contracts, and another unit of account with fixed purchasing power used for long-term contracts. In actual fact, all Hall is doing here is revealing the effective duality of units of account in present-day economies: in practice one of their major characteristics, so naturalised and so obvious that it no longer strikes anybody. Are national accounts not drawn up both in (nominal) value and in

\footnotetext{
${ }^{9}$ On the origins of CDP see Gomez-Betancourt \& Boyer des Roches, 2013.
} 
volume ("real" value), i.e. in a nominal unit ("current" money) and in a "real" unit ("constant" money) deflated by the new price index - as is UF? What is new with UF is that this "constant" indexed unit of account is not only a unit of account but indeed is also "monetised" and used from day to day (potentially) in some specific market and fiscal transactions ${ }^{10}$.

All in all, over and above the diversity of the standards envisaged, the NME turns out to be drawing inspiration largely from Irving Fisher and his compensated dollar plan, even though this is sometimes denied. Fisher's is the explicit thinking of reference not only for Hall, but also for Black and Fama. As for Yeager and Greenfield, though they stress the differences between their model and Fisher's CDP, they do admit that the two systems come close to one another (Yeager \& Greenfield, 1989, 418-419). Thus Sumner sees YGS as " $a$ privatized version of Fisher's compensated dollar" (Sumner, 1009, 117). Schmitt \& Whittaker (henceforth SW) feel that YGS differs from Fisher's CDP only in that its price adjustments are continual and not simply periodical (SW, 1993).

The mechanism common to the arrangements envisaged by Fisher and by the NME to stabilise overall price levels is modification, according to a fixed rule, either from day to day or periodically, of the value in terms of the unit of account of the unit of "resource" - whether it is a commodity, a bundle of commodities, a financial asset, or a fiat currency - used as the medium of account which serves as a material basis for the unit of account.

In actual fact, our examination of the "weak plurality" of moneys in the NME leads us to conclude that the stumbling block of the system is not merely its stability but also the actual unicity of the unit of account. To solve the problem of stability of the overall price level, NME is led either to imagine systems that are not operational and / or viable even in the eyes of their own advocates - this is the case with YGS, criticised by SW (1993) and CK (1994) - or to return to government regulation put paradoxically at the service of LaissezFaire. The principle of competition and the purpose of making money totally endogenous run into their limits here, and the iconic central figure of Walras' auctioneer with his arbitrary currency, inevitably reappears.

Thus the NME is torn between the plurality claimed by private issuers of means of payment, and the a priori principle of unicity of the unit of account. Moreover, it turns out that the viability of competing systems of payment, which theoretically no longer require base money, depends paradoxically on maintaining a money that does not carry interest and is based on a stabilised unit of account. Thus CK conclude their comparative study of the different monetary systems envisaged within the framework of NME by opining that "the scenario with financial assets [as medium of exchange] and currency [as medium and unit of account] is the most likely to evolve from a deregulation of today's financial institutions" (CK, 1994, 100). The plurality claimed for means of payment would thus draw "strong" plurality into a world cohabited by units of account that are more or less indexed and monetised. CK, however, who are relatively close to the Mengerians, are the only advocates of NME to explicitly acknowledge the unsustainable nature of an a priori principle of unicity of the unit of account, and from the outset position themselves within the framework of "strong" plurality. They do not hesitate to advocate a return to a world where as in the Middle Ages, there were a proliferation of moneys of account and payments, a world in which new technologies of information and communication would subsequently make it possible to represent as perfectly rational, with transactions coming cost-free. We must now to take a closer look at this.

\footnotetext{
${ }^{10}$ Indeed, in Chile tax and some public expenditures are also expressed in UF (Shiller, 2002).
} 


\subsection{Plurality extended to units of account. The rationale and "motivations of multiple media of account" in CK (1994)}

Despite the plurality of monetized indexed units of account emerging from the thinking of Hall $(1997,2002)^{11}$, CK are the only declared proponents of the NME who stress, referring explicitly to Rothbard (1962) and to Hayek (1978), "the possible proliferation and co-existence of different currencies of account at advanced stages of financial evolution" (CK, 2010, 39). "In an unregulated environment, the evolution of multiple media of account follows a path similar to exchange media and settlement evolution. (...) Even if consumer convenience dictates a common medium of account for most retail transactions, we still expect medium of account proliferation for large wholesale and financial transactions. (...) In advanced stages of financial evolution (...) economies will be composed of regional and sector-specific 'optimum medium of account' areas, to draw upon Mundell's (1961) concept of optimum currency areas" (CK, 1994, 38-39). "The costs of using multiple accounting media also fall as financial evolution progresses. (...) Efficiency implies the development of multiple MOA (medium of account) within a single geographical area" (ibid., 16).

Similarly, CK believe that in the framework of a YGS several units of account initiated by banks should compete, each corresponding to different baskets of commodities selected to represent the differing costs of living of social groups targeted as clienteles. "The value of a bank account, for instance, can be linked to the value of a chosen medium of account (...). (...) In effect, the depositor is a creditor of the bank and returns are denominated in terms of chosen accounting media. Account linked to the value of regional or personal consumption baskets would give rise to multiple mediums of account in this context" (ibid.).

This raises the question of the bases on which the markets set the exchange rates between different moneys ${ }^{12}$. It also raises a second question: what is the cost of information in such a system, compared to the routine solution suggested by Yeager ${ }^{13}$ that consists in simply aligning the unit of account with that used by government in its operations and fiscal policies?

In a framework of general equilibrium, or in that of the Austrian free banking approach, the unicity of the unit of account applicable to a given space is almost unanimously considered to be an inescapable economic requisite, as it makes transaction costs lower than in a system with multiple units of account, especially as it limits exchange-rate risks. Since CK position themselves in these same theoretical frameworks, which they hybridise, their focus on pluralization of units of account does not look quite consistent, if not to reveal the instability of multiple means of payment when there is only one unit of account, as in Hayek (1979). Moreover CK's transposition of Mundell's idea of an optimal monetary zone which is in reality a justification of the unification of units of account extended on broader and broader scales, enable us to interpret CK's position as tending towards a unicity of units of account in homogeneous monetary spaces, with only the spatial or social scales being variable. CK do of course refer to fractioning by region or sector of optimal single account-currency zones, thereby raising the whole problem of the fractioning of spheres of exchange in the economy. This however contradicts the hypothesis of homogeneity of the TEG on which their argumentation is nonetheless based. CK recognise this fact when they say that "heterogeneity of traders plays a critical role in this use of multiple medium of account" (CK, 1994, 41),

\footnotetext{
${ }^{11}$ Practically at the same time as Shiller $(1998,2002)$.

12 The next section deals with private fiat moneys.

13 "The government must choose a unit of account for its own spending, taxing, borrowing, lending, and accounting. Its choice will give private parties a reason to adopt the same unit. It will thus have a role in suggesting the basket or price index to define the unit, at least initially" (Yeager, 2010, 434).
} 
whereas "with perfect liquidity and perfect markets medium of account choice would not matter and the motivations for multiple medium of account would disappear" (ibid., 43).

\section{Neo-Mengerian approaches to money: between plurality and unicity of units of account}

Though NME (in particular with Yeager, and Cowen and Kroszner) has been influenced by Menger and Hayek, the previous section has shown that it should be clearly distinguished from typically neo-Mengerian approaches. These approaches can be subdivided into two main types. One of these stems from the competitive fiat moneys model of Hayek and Klein (3.1). The other derives from the already dated Free Banking tradition that was deepened and renewed by Selgin and White (3.2).

\subsection{Competitive private fiat money and the denationalisation of money: the principle of absolute plurality}

The idea of monetary competition applied to instruments of payment and to units of account was developed in the 1970s and 1980s, in particular by Klein (1974) and subsequently by Hayek $(1976-78,1979)$ who claims to have reached exactly the same conclusion as Klein without having had any knowledge of his writings. Vaubel has also discussed this question in several articles (esp. Vaubel, 1984 and 1986).

The competitive fiat money model formulated by Hayek (1976, 1978) can be distinguished from the NME by the fact that it does not preclude public money. It can be distinguished from the free banking system, in which banks issue inside money convertible at par and at demand into outside money (e.g. metal coins) selected by the system of payment itself. Hayek's model corresponds to an endogenisation, within national territory, of competition between moneys that exists on the international level.

According to the competitive fiat money system, each bank has its own distinguishing mark (the unit of account), which it uses to denominate its money (or means of payment). There is not a priori a common unit of account (e.g. the "pound sterling") as is the case in the free banking system or that of central banking. On the one hand, agents are able to differentiate between moneys thanks to their fluctuating exchange rates and thus bear the exchange-rate risk. On the other hand, they are free to choose the money that in their view holds promise of the best stability in terms of purchasing power. Banks can rely on - or construct - a price index to help them monitor the stability of the money selected. The basic idea in this model is that monetary regulation is determined more by the quantity of money put into circulation by the issuing bank than by the ability of the bank to reimburse on demand its debts in an outside money (in coin or public money). Indeed, (Hayek, 1978, 42) supposes that the issuing bank will announce its "intention to regulate the quantity of [its money] so as to keep [its] (precisely defined) purchasing power as nearly as possible constant".

If the quantitative regulation of competitive fiat moneys constitutes the mechanism determining their purchasing power and exchange rate, competition between banks sets an "effective limit" to these (Hayek, 1978, 44; idem. 1979b, 4). Plurality is thus appreciated essentially from the viewpoint of competition and discipline on the money market. For Hayek, money draws its legitimacy essentially from the stability of its purchasing power; in a 
competitive environment, a bank can therefore decide whether or not to increase its money supply. If its money appreciates, the bank can issue new means of payment and/or buy rival moneys according to its clients' demands. If its money depreciates and the quantity of its money on offer exceeds public demand, it stop roll over credit and/or sell off its reserves of rival moneys. Thus, in formulating the competitive fiat money model, Hayek $(1978,55)$ feels that he has found a way of regulating and constraining the banking system so that it will offer only short-term loans. "In order to retain control over its outstanding circulation, [the issuing bank] will on the whole have to confine its lending to relatively short-time contracts so that, by reducing or temporarily stopping new lending, current repayments of outstanding loans would bring about a rapid reduction of its total issue".

The distinction between the different competitive fiat moneys also enables the Hayek model to avoid criticism based on Gresham's Law, according to which bad money drives out the good one. This principle initially applied to coinage of the same metal and involved two factors: (i) clipping, wear and tear of coins or debasement and (ii) maintenance of fixed legal parity between moneys. Since there is a difference in the market prices of two coins, the coin of better quality tends to be withdrawn from circulation (hoarded, smelted or exported). If there is no fixed exchange rate between the two coins, both the bad and the good coins would parallely remain in circulation at a discount and premium. Similarly, with a fixed exchange rate between competitive fiat moneys, conservative banks would be penalised in comparison with expansionist banks that would increase their market share by increasing the volume of their loans without this leading to a depreciation of their money. Eventually all banks would behave in the same expansionist way, and the end result would be monetary chaos. Flexible exchange rates, despite their drawbacks, are thus essential if the competitive fiat money model is to be viable, through the mechanism ensuring that stable money drives out money that has depreciated.

To designate the unit of account proper to each bank, Klein (1974) uses the term "trademark" or "brand name" and suggests applying the concept of property right to each monetary brand name, but only to banknotes. Similarly, Hayek (1979b) uses the term "distinctly named money". In their view, forgery (i.e. infringement of the bank's property rights) would apply only to counterfeit banknotes. Forgery could thus be defined as the illegal reproduction of banknotes using not only the name of the issuing bank, but its unit of account. A prejudice results from this infringement of property rights. From a quantitative viewpoint, it corresponds to an over-issue not desired by the bank, leading to a depreciation of its money, loss of clients' confidence, and deterioration of its reputation and of the value of its trademark. This means that banks would have interest in keeping a careful check on the quantity of their notes in circulation. This being said, to take only the quantity of banknotes in circulation into account would be too restrictive: deposits should not be overlooked. The property rights should be applied to the levels both of banknotes and deposits and the legislator should take this issue into account (Le Maux, 2007). In this respect, the experiment of the eurodollar market gives us a better grasp of the problems raised here, and also of the difficulties implicit in the protection of property rights to the monetary trademark. The central banking system and even the free banking system (to be dealt with below) do not entail difficulties of this sort: the unit of account is unique and it is a public good that issuing banks can use.

\subsection{Free banking as a return to monetary unity}

Hayek, like Klein, has criticised the free banking system, which he sees as an incomplete system of monetary competition. Unlike the competitive fiat money model, the 
free banking system corresponds to a theoretical and historical tradition (White, 1984b; Selgin, 1988; Dowd, 1992; Selgin and White, 1994). Under this system, banks are free to issue notes and deposits (inside money) that are convertible at a rate of one to one into an outside money such as coinage. A recurrent misunderstanding of the free banking system stems from the fact that convertible banknotes have always been associated with inconvertible paper money. The free banking system is often erroneously seen as a system in which bank issues of money fluctuate in relation to one another (for instance in Baye, De Grauwe \& De Vries, 1993).

During the early time of a free banking system, banknotes can if necessary be changed at a discount, especially if the exchange is organised by brokers. The rate of discount would depend on costs of transport and authentication and also on the risk of default. The discount setting, however, does not last. There is an incentive for banks to organise themselves a clearing system of compensations - bilateral at first, then multilateral - that enables them to reduce the rate of discount and finally to do away with it. Then, the par exchange of banknotes and deposits reinforce their acceptability among the public. Of course, the costs of transport, sorting and authentication are lower thanks to centralisation of the exchange of issues and to economies of scale in physical and financial quality control, and they are henceforth borne by banks that are members of the clearinghouses, and not directly by the bearers of banknotes. The risk of default inherent in each bank does not prevent its notes from being rated at their face value. As a result, the bank issues fall into line with the official unit of account.

The free banking system thus stands at the intersection of the unicity of money and the plurality of banks. The unicity of the unit of account is preserved. The State defines the country's unit of account in terms of the weight of precious metal it contains, and the Mint coins specie. The plurality of monetary signs springs from the fact that banknotes and bank deposits bear signatures that vary according to the issuing authority. To some extent, the free banking system can be compared to the central banking system, inasmuch as there is a unique unit of account and as the banks issue debts at sight that are convertible into an ultimate money: specie in one case and central bank money in the other. The difference lies in the fact that under the free banking system (i) the ultimate money is exterior to the banking system and the monetary authorities, and (ii) the degree of bank regulation is very slight. The free banking system entails neither an abandon of centralisation of money reserves and interbank clearing operations, nor that of a unique unit of account. It sets up a high degree of deregulation of banking and tends towards an abolition of the lender of last resort.

Competition is thus limited to that between the different inside moneys, i.e. between demand debts issued by banks in the form of banknotes or deposits. The outside money, which preserves the regulation of the system, is not involved in competition. This is the last component of monetary policy still retained, though admittedly in atrophied form, by the free banking system. Moreover, money is first and foremost treated as a commodity invested with qualities that lend themselves to its use as money (Menger, 1892). If fiat money emerges and is accepted at face value, it is felt that no matter how far one goes back in time, it must initially have been linked to coin, by virtue of its convertibility (Mises, 1949). Selgin (2003) deals with the hypothesis of adaptative learning in order to show the transition from the metallic standard to the fiat money standard.

To sum up, in the NME competitive payment system in which the unit of account is separated from the means of payment, agents bear the risks that burden assets. In the Hayekian competitive fiat money, agents bear exchange-rate risks. Under the free banking 
system, in contrast, the unit of account is a public good and agents bear the liquidity risks entailed in the issue of demand debts. The competitive fiat money model advocated by Hayek and, to some extent, the NME models, would seem to be much more radical than the free banking system. Whereas the former entail a middling degree of a plurality that is strong or even absolute, the latter show a weak plurality that is based on the unicity of the unit of account.

\section{Integrating money into the general equilibrium theory}

A huge part of the economic theory of money deals with the conditions governing its integration into the framework of the general equilibrium theory (GET). The latter was developed without taking money into account. Trying to solve this omission raises two questions: the Hahn Problem (Hahn, 1965; Hellwig, 1993): how can fiat money have a positive value in exchange, when it has no intrinsic utility; and the Hicks Problem (Hicks, 1935): why does an agent hold money in a universe in which there are remunerated assets?

The answers to these questions have been thought out in many ways. Following Walras, Patinkin (1956) opened up one line of thought, making money part of the utility function of agents. The trouble with this "monetary Walrasianism" (Mehrling, 1998) is that it has never been possible to make money appear in it with a positive price. Difficulties inherent in monetary Walrasianism led research to other avenues, in which some assumptions in the Arrow-Debreu model were relaxed (Benetti, 2001). As of 1935, Hicks used the concept of frictions with this in view. Among the avenues explored that gained significant notoriety, the first - that of overlapping generations models (henceforth OGM) - ran into a stumbling block by focusing almost exclusively on the reserve function of money (section 4.1). As a result, two other avenues were explored, focusing on the contrary on the function of money as a medium of exchange: the cash-in-advance (henceforth CIA) (section 4.2) and the searchtheoretic models of money (henceforth SMM) (section 4.3). Monetarism in the manner of Friedman, on the other hand, proposed a strongly asserted normative framework that stresses the need for centralisation and unicity of issue (section 4.4).

\subsection{The Overlapping Generations models}

Overlapping generations models (OGM) are first and foremost analytical tools with a broad field of application. Monetary theory is not their main objective. In general, they have been used only marginally in theorising money.

\subsubsection{OGM and money}

The basis for these models was established in a article published by Samuelson (1958), without referring to prior suggestions on the subject by Allais (1947). It played a pivotal part in making the hypothesis of overlapping generations known. In this type of model, an economy is seen as being set up by two successive generations of agents, one young and active and the other older and inactive, over a non-finite series of periods. Trade involves goods that are perishable from one period to the next, making it problematic to hand down wealth from one generation to the next. How can this be done? Samuelson (1958) shows that without money no trade can take place. The general characteristic of OGM is that the general 
equilibrium can be sub-optimal in Pareto's sense of the term. This initial model was completed by the approach of Diamond, who came up (1965) with the canonical model of overlapping generations. This theoretical ensemble is one of the prolongations of Walras' theory of competitive general equilibrium, though it deviates from the theorisation of Arrow and Debreu.

In these models, money is a "social contrivance" or a "social compact" (Samuelson, 1958, 481-482), which enhances the utility of all agents involved. The main strength of these models, compared with the Arrow-Debreu version, is that money has a utility, as without money exchange could not take place, and money is thus given a positive price. Money is first and foremost a perfect arrangement for conserving wealth (its reserve function). It is because money is a tool for inter-temporal allocation of resources that it is used in trade. Nothing is said about its role as a medium of exchange, and even less about its use as a unit of account (not observable in these models apart from assumptions on price level). The absence of the medium of exchange function has consequently been strongly criticised (see the debate in Kareken \& Wallace, eds, 1980, and McCallum's critique, 1983).

However, though the initial models and those used since Samuelson (1958) do not deal with money, or do so only incidentally, some of them have nonetheless been designed specifically to integrate it into general equilibrium theory (GET). From Wallace (1977) onwards, and other work done circa 1977-1978 (Kareken \& Wallace, eds, 1980), OGM have been designed to study the money demand function, distancing themselves from the frictionfree world of GET, so that the existence of money can be explained by its usefulness as a "lubricant" (Wallace, 1977). In this particular framework, money can only have value if the number of generations involved is non-finite: for the young, what counts is that money should still be acceptable when they are old. Unless this were the case, the young would not accept money; thus there can therefore be no such thing in this system as a last generation (Wallace, 1977; Orléan, 2009).

\subsubsection{Monetary plurality in the OGM}

Examining the problem raised by the coexistence of fiat money and financial assets with a positive yield, Wallace (1980), and subsequently Kareken \& Wallace (1981) feel that for fiat money to continue to exist under these circumstances, it must have a particular utility of its own, and be evaluable, which OGM make it possible to show. Wallace (1983) concludes that the only thing that could explain this is that because of legal restrictions it is impossible to substitute financial assets for money.

Besides this, Kareken \& Wallace (1981) have sought ways of dropping the hypothesis implicit in monetary theory in general, according to which residents of a given country seek to hold only that country's currency. Their objective, here, was to explain phenomena of currency substitution that were drawing increasing attention because of the high inflation reigning in Latin America ${ }^{14}$. They proposed a model that had two fiat moneys in circulation in the same country with an internal exchange rate that could vary - a situation purportedly characteristic of a regime of laissez-faire.

In monetary theory, the OGM lead one to envisage monetary plurality as the coexistence, within the same territory, either of a fiat money and financial assets held by agents and susceptible to be used as means of payment, or of several fiat moneys. In both cases, plurality is conceived of as competition, either between assets and moneys, or between

\footnotetext{
${ }^{14}$ This analysis was subsequently developed, in particular by Chang (1994).
} 
moneys, both being seen as mutually substitutable, with only legal restrictions preventing fiat money from disappearing. This is what the NME current suggested, as we have already seen. However, contrarily to what is sometimes asserted (Hall, 1982a ; Hoover, 1988), the NME and the theory of legal restrictions in its initial formulation by the Minnesota school, do not really coincide. Whereas the NME is in favour of a complete deregulation of the monetary system, Wallace and his colleagues feel on the contrary that some legal restrictions to the issue of money and to banking practices are justified, in particular in the international sphere (Kareken \& Wallace, 1978; Wallace, 1979). Besides this, the Minnesota school seeks to integrate into the general equilibrium model the "friction" that is base money rather than to eliminate it, as suggested in the NME, in whose view the GET shows not only that base money is unnecessary, but even that it is an obstacle to maximisation of "well-being" (Hoover, 1988, 151; Yeager, 2001). Lastly, the Minneapolis economists, contrarily to the NME, are hostile to any competitive issuing of fiat money, which they find "either inefficient or infeasible" (Bryant, 1980, 1).

\subsection{Cash-in-advance models (CIA)}

Clower $(1967,5)$ attempted to found the utility of money on its function as a medium of exchange, taking as a basic principle that "money buys goods and goods buy money, but goods do not buy goods." He broke with the Walras-Debreu-Patinkin approach, according to which money is brought in only once a theory of exchange has been constructed. According to Clower, fiat money is exogenous to the system, and in each period individual expenses cannot exceed the amount of money already held. This is the cash-in-advance (CIA) constraint. This idea answers a question as to the costs of transactions: exchanges of money lower the latter, as bartered goods do not have the durability, divisibility and portability of money.

In general, CIA models maintain a distinction between financial assets and fiat money, and their reasoning involves a single money in a configuration of absolute unicity. Though the CIA models make it possible to formulate a function of demand for money (for instance Lucas \& Stokey, 1983), they do not explain, however, why exactly money exists (Duca \& Van Hoose, 2004). Thus, for Kiyotaki \& Wright (1989, 928), they "have no hope of explaining endogenously either the nature of money or the development of monetary exchange".

Despite these limits, monetary plurality can in fact be built into the CIA models. This has been done, e.g., by Sturzenegger $(1992)^{15}$, who refers to the Argentine and Brazilian experiences. Considering a situation of high inflation that leads to the formation of two "currency circuits", Sturzenegger (1992, 4 \& 23) asks what the effects would be of agents' adapting to the dual circulation, one of goods sold for domestic currency, and another of goods sold by means of an alternative "inflation-proof technology" (e.g. dollarization, or interest-bearing cheque accounts, alternative money commodities, or even credit cards). This coexistence of two forms of money is thus conditioned by technological restrictions that result in transaction costs: the costs of changing money and of access to technologies enabling agents to use forms of indexation. The sum of these costs prevents the national currency from being completely replaced by alternative means of payment. This constitutes a theory of imperfect substitution of money.

All in all, CIA models look on money as a medium of exchange. In a situation of plurality, the substitutability of moneys is imperfect because of costs of the various

\footnotetext{
${ }^{15}$ See also Uribe (1997).
} 
transactions associated with each of them.

\subsection{Search models of money (SMM)}

Various developments in the theory of money have analysed the money / barter alternative from the viewpoint of both the Mengerian problem of the emergence of a unanimously accepted money (Menger, 1892), and Jevons' question on the double coincidence of needs (Jevons, 1875). In this respect, search models of money (SMM) constitute models of decentralised economy. Starting with the idea that the medium of exchange is the main function of money rather than the store of value, they seek the endogenous causes of the selection of one money by agents, attempting to go beyond the CIA ad hoc assumption of the existence of a means of exchange (Kiyotaki \& Wright, 1989). The SMM are set up as truly neoclassical theories of the genesis of money. They model agents' choices between several modes of transacting, usually with recourse to money on the one hand and to barter on the other. Once all the agents involved have selected money, they must actually hold money before any transaction can take place. The foundational model proposed by Kiyotaki \& Wright (1989) deals with two possible cases in a decentralised market economy that requires a means of exchange in order to effect random bilateral exchanges. The first case explores the possibility of emergence of a money on the basis of the selection of one commodity among others. This selection is based on a combination of properties of the goods in question and beliefs concerning them. This commodity money, however, presupposes a situation that is not Pareto-optimal. In the second case, a fiat money is introduced with the effect of increasing well-being.

Selection of a money by agents has been formalised by Iwai as "a bootstrap mechanism" (Iwai, 1988, 1996). His model proposes to solve the non-determination of equilibrium (due to absence of an element weighing in favour of either money equilibrium or barter equilibrium): it hypothesises a small group of agents who begin to choose a general medium of exchange; when this happens, the other agents soon follow this initial choice because of the increasing returns it promises: "money is money simply because it is used as money" (Iwai, 1996, 452). A monetary equilibrium of this sort thus entails absolute monetary unicity.

From search models can be deduced an alternative between equilibrium with money and equilibrium without it, yet combined equilibria are possible. Though monetary plurality is not usually a subject dealt with in thinking of this type, Kiyotaki \& Wright $(1991,1993)$ clearly mention the possibility of accounting for the existence of monetary equilibria involving several fiat moneys. With this in view, these authors present a model that involves two fiat moneys and a real commodity. This model reveals the variable articulations between these means of exchange according to their yield levels and their partial or universal acceptability. It opens up the possibility of simultaneous circulation of two currencies, even if in terms of profitability or acceptability the one dominates the other.

Work on a possible plurality of moneys within the framework of search modelling has been very limited, however. Kocherlakota \& Krueger $(1999,243)$ draw attention to this weakness, dismissing this type of model as well as OGM: "even the 'deepest' models of international currencies do not give rise to a motivation for having different currencies". To move forward, they construct a signalling model of individual preferences in commodities on the basis of a random matching model in the territory of a country. Agents are presumed to be sensitive to the national origin of the commodities in question, but this origin remains private information. Agents' preference for one money rather than another thus serves to reveal their preferences as regards commodities (according to their country of origin). Money here is a 
medium of information between supply and demand. The model thus applies to multiple currencies, which it reduces to two (national and foreign currency), with a fixed rate of exchange, between which the agents can choose prior to the process of matching. Kocherlakota \& Krueger assume that the agents have a preference for their own country's products, but that the sellers are not opposed to the use of foreign money, nor are the buyers opposed to the purchase of a foreign commodity. The authors conclude that "multiple national currencies may play an essential role in achieving an optimal allocation of resources" (1999, 243).

To sum up, the implicit vision in SMM is that of a money that is initially a medium of exchange, even though theoretical derivatives may give it an informative function (Kocherlakota \& Krueger, 1999, but also, further from the search function, Kocherlakota, 1998). Its qualities (and particularly its saleability) make it a liquid and fungible tool that gives rise to one equilibrium among others. As Cartelier (2001) stresses, however, the problem of the nature of money is not solved by this: though the model provides progress towards solving Hahn's problem, it still does not enable us to reason on the nature of money: the bootstrap disregards the question of "the reasons for which an object has been chosen as the exclusive medium of exchange" (ibid., 1000-02). Nominalist and realist approaches can both be accommodated within it! The solution is exogenous, introduced by hypothesis.

In the neoclassical and new classical models presented here, money is treated as an asset without intrinsic utility, and does not bear interest. There are consequently two series of possible choices: one of them is between money and goods endowed with intrinsic utility, and the other is between money and assets bearing interest. Unicity of money is thus generally presupposed, and it is absolute. Money is thought of as enhancing agents' well-being by facilitating trade, and indeed by enabling trade to take place. Complex forms of equilibrium including money and barter have also been developed. When a plurality of moneys is being dealt with, what is done is to present, in the range of options offered to agents, different national and fiat moneys. Absence of thinking on the subject of the unit of account, however, makes it impossible to position this conception of plurality accurately on our scale of configurations of strong and weak plurality. A noteworthy feature is the absence of regulation and homogenisation of the different moneys by means of a guarantee of parity and even of convertibility by an overseeing authority.

\subsection{Monetarism}

Monetarism is noted for the normative stress it places on monetary unicity. The particularity of the quantity theory is not so much its postulate of a proportional causality from the variation in the money supply to the variation in the overall price level, as its application of this postulate to all forms of money, whether metallic currency, fiat money or convertible bank issues. The quantity theory thus sees the question of money as that of a homogeneous mass of means of payment immediately available in front of agents' eyes, an aggregate of means of payment to be measured and controlled. Furthermore, the homogeneous mass has no effect on real variables and on the system of relative prices in the long term (and even in the short term). This makes it neutral (or super-neutral). If money is neutral in theory, it should also be neutral in practice. With regard to the monetary plurality, money should by no means be produced by private institutions such as commercial banks. As Friedman writes $(1959,7)$, "The production of a fiduciary currency is, as it were, a technical monopoly." 
The stumbling block facing the quantity theory has always been the construction of the monetary aggregate, which is perpetually destabilised by the diversity of monetary practices. Moreover, the very action of the central bank in attempting to control the aggregate leads to a destabilisation of the aggregate itself. Among the quantity theorists, Allais (1975) concludes that in a system of credit in which commercial banks "create money", the quantity of money is essentially a "subjective" variable, depending on agents' practices in spending and saving. This being the case, what has to be done is to establish a regulatory framework applying to banking and financial institutions so as to set up once and for all an "objective" definition of the quantity of money, over which the authorities can then exercise sovereign control. Various reformulations of the idea of a government monopoly on the issue of money may be found in the writings of Simons (1934) and Fisher (1935), who formulate the Chicago Plan. The principle of a government monopoly of the issue of paper money and demand deposits was subsequently adopted by Friedman (1959) and Allais (1993).

From an institutional point of view, the idea of the Chicago Plan was that government should exercise in full its sovereign right to control money both as a unit of account and a means of payment. In other words, the unit of account is the monetary brand name of the State, which should have the exclusive right to use it. Thanks to these powers, the government could then pursue a policy aimed at gaining complete control of the monetary aggregate and thus stabilise the purchasing power of money. In a situation of laissez-faire, however, practices in the private sphere, and particularly in that of banking, can lead to infringement of the government's sovereign right. Banks that issue monetary signs are thus freely engaging in what amounts to "counterfeiting", and this should be forbidden. Thus by requiring banks to hold $100 \%$ of their reserves, i.e. to back all their demand liabilities by the central bank money in reserve, the Chicago Plan deprives banks of all monetary initiative.

From both positive and normative viewpoints, the quantity approach is no doubt the most extreme assertion of monetary unicity within a sovereign territory in which the State guarantees the unicity of the unit of account. Monetary plurality is seen simply as counterfeiting, a violation of sovereign rights. Finally, of all approaches to money, that of the Chicago Plan economists asserts most forcefully the principle that money is State. Paradoxically, however, the institutional arrangements offered by the Chicago plan have never been adopted in the Chartalist approach.

\section{Keynesian and Marxist approaches to money}

Most of the approaches described in this section are based on Marx or Keynes' theories. They share the view that money is a sine qua non for an economy of production, and so much so that "an understanding of money as socially accepted token of value in Marx's monetary theory of value is perfectly compatible with the post-Keynesian view of a modern credit money system" (Hein, 2004, 8-9).

Within this theoretical framework, shared by a wide range of approaches, from neoChartalist and post-Keynesian to contemporary Marxist, the idea of plural moneys would seem to be hardly conceivable otherwise than as a pathology and the expression of a plurality of qualities and levels of acceptability of means of payment. On the one hand, this line of reasoning is opposed to the approach of contemporary financial economics (NME) that values monetary plurality as an expression of competition between private currencies: for postmarxists and keynesians, this is a problem to be faced; for the others, a solution. But on the other hand, this thinking is to some extent drawn towards financial economics, as it also 
shows concern for the monetary impact of the plurality of debts and financial units of account.

\subsection{Chartalism and post-keynesian}

For most of the neo-Chartalist and post-Keynesian currents of thinking, Knapp and Keynes provide the essential components used to construct a coherent monetary theory according to which the separation of the monetary from the real sphere is irrelevant. Money is "a social reality within the system: a non-commodity in a universe of commodities" (De Vroey, 1984, 383), an "institution" (Rochon, 1999).

According to Knapp, considered to be the first Chartalist, if the unicity of money in a political territory is a fact beyond doubt, payments, in contrast, can be distinguished from one another by taking into account the parties involved. "Payments to which the State is a party, either as giver or receiver, will be called centric, because the State is regarded as the centre from which the ordering of business radiates. Payments in which the State takes no part either as giver or receiver we call paracentric; such are all payments between private persons" (Knapp, 1924; 96). In his Treatise on Money published in 1930, Keynes claims to be a follower of Knapp: "Today all civilised money is, beyond the possibility of dispute, chartalist" (Keynes, 1930, 4). However Keynes was to neglect State money subsequently and to focus above all on bank money and what he termed the "financial circulation". In many articles published after the Treatise and related to the "finance motive" (Keynes, 1937), he was to focus his analysis on the monetary economies of production (capitalist market economies).

Similarly, post-Keynesian and (neo)-Chartalist currents share many views. It is nonetheless necessary to distinguish between them, as "not all Chartalists are postKeynesians, and not all post-Keynesians are necessarily Chartalists, though the overlap is admittedly large" (Goodhart, 2005, 817). Whereas the (neo-) Chartalists concentrate more on the creation of State-money, and particularly on the way in which monetary unicity is established within a territory, post-Keynesians are mainly interested in bank-money and the diversity of types of debt.

Absolute monetary unicity would seem to characterise neo-Chartalist thinking, and weak plurality (of bank moneys when there is not a single-bank regime) that of the postKeynesians. A stronger plurality may be conceived if both State money and bank money are taken into account.

Having succinctly described these two approaches, we will now stress their convergences, without overlooking the tensions that can arise between them and can lead to conceive a certain plurality.

\subsubsection{The Chartalist option: plurality as a symbol of "imperfect sovereignty"}

Lerner (1947) and more recently Wray $(1998,2003)$ have revived Knapp's vision of money as a creation of the State: "[...] at the present time, in a normally well-working economy, money is a creature of the state. Its general acceptability, which is its all-important attribute, stands or falls by its acceptability by the state" (Lerner, 1947, 313). Fiat (or State) money is "the money used as the link between the public and the private pay communities. It is the money that sits at the top of the debt pyramid (or hierarchy), or the 'definitive' and 'valuta money" (Wray, 1998: 77). "The Chartalist argument, that state money is base money because of acceptability in the payment of taxes, is obviously a powerful one. [...] It is easy to see, therefore, why historically/empirically the state with its coercive powers has been in the driver's seat" (Lau \& Smithin, 2002, 19). 
The neo-Chartalist current rejects use of the term money in its fullest sense when applied to any instrument of payment that is not official. Despite a multitude of historical examples that weaken this position, the Chartalists assert that the principle of "One nation, One money" is logically indisputable. Fiscal systems can rely on currencies other than the central money, but these are merely examples of "imperfect sovereignty" (Wray, 2010, 42), given that "sovereignty can be defined as the ability to impose tax liabilities" (Wray, 2003, 90).

\subsubsection{Monetary unity and diversity of debts: the post-Keynesians}

In the late 1950s the Radcliffe report (1959), Minsky (1957), Kaldor (1960), and Rousseas (1960) maintained that the money supply was "credit-driven" (Niggle, 1991). This line of research was pursued by Davidson (1972), Kaldor (1982), and Moore (1998), in whose view, instead of reasoning in terms of the mass of the money supply, we should analyse with precision the mechanisms of the demand for credit. The reason for this is that the money supply is perfectly elastic and is endogenous to demand: "in a credit economy the money supply is necessarily endogenous, not exogenous" (Kaldor, 1981, 455), whereas: "in the Friedman and Lucas constructs the money supply is 'exogenous' in the sense that the central bank can determine what happens to the money supply." (Minsky, 1986, 346). The postKeynesians attempt to describe the endogenous nature of money creation, which they consider to be characteristic of modern economic systems. "Credit money has no supply function in the conventional production function sense of the term. In the Treatise, Keynes insisted that money 'comes into existence along with debts' - in other words, the supply of money is related to contracts and the debts they necessitate. Money does not enter the system like manna from heaven - nor from the sky via Friedman's helicopter" (Moore, 1988, 374).

There is general agreement among the post-Keynesians that (i) in distributing loans the banking system responds to demand, and (ii) that its hierarchical organisation guarantees compensation and homogeneity of the credit money. However, though the endogenous nature of the money is admitted by all, it is not always thought of in the same way when the curve linking money supply to interest rate is flat as when it gradually rises ${ }^{16}$. The "horizontalists" (Kaldor, Moore, Lavoie) see the endogenous nature as complete; for the "structuralists" (Dow, Goodhart, Pollin), it is only partial. In actual fact, three currents should be distinguished, insofar as horizontalists are divided into two groups, the Americans tending to privilege money as a variable of stock, while the Europeans see it as a variable of the flow that is required to finance spending (Wray, 2003).

Horizontalism (or "accomodationism") "is perceived as a passive response of the financial institutions and authorities to the economy's production needs. [...] Short-term demand for bank loans determined by the working capital financial needs of firms" (Panagopoulos \& Spiliotis, 2008, 602). "Money is credit-driven; loans make deposits; deposits make reserves. The supply and the demand for credit are interdependent. The control instrument of the central bank is not a quantity but a price, the rate of interest." (Lavoie, 1992, 170). They also feel, besides this, that "the money supply creation (and destruction) process is the result of the links between three categories of actors - banks and firms, firms and workers, and banks and households. The first one is responsible for the creation, the second for the circulation, and the third for the destruction of money" (Panagopoulos \& Spiliotis, 2008, 605).

Lastly, the structuralists feel that "...the central bank is a significant player and has

\footnotetext{
${ }^{16}$ See Moore (1988, 1991), Goodhart (1989), Dow (1996), Piégay \& Rochon, eds (2000).
} 
the privilege to deny accommodation of reserve needs and consequently resist credit expansion." (Panagopoulos \& Spiliotis, 2008, 603). "A decreasing liquidity position of commercial banks and rising lender's and borrower's risk in the accumulation process finally lead to rising interest rates when the quantity of credit is expanding" (Hein, 2004, 24). The central bank is thus only partially accommodating. In this approach, the diversity of monetary markets turns out to be problematic, as Minsky has often pointed out.

\subsubsection{State Money versus Bank Money?}

As has been stressed, Keynes' monetary analysis in his Treatise is ambivalent. He sees State Money as money proper, but subsequently proceeds as though only "Bank Money" were worthy of interest (Moore, 1998). It is the tension between the two types of money that leads to a divergence between neo-Chartalists and post-Keynesians.

Post-Keynesian "horizontalists" consider that the State cannot be seen as the initiator in creating money (Mehrling, 2000; Gnos \& Rochon, 2002; Rochon \& Vernengo, 2003). Opposing them, Wray $(2003,91)$ adopts the logic of the taxes-drive-money view in which the State is "the monopoly supplier of currency", and proposes to "consolidate the central bank and the treasury, calling the conglomerate 'the State". Moving on to assert that State money appears to be determined in an exogenous way by the government, in accordance with fiscal logic, is an easy step; once it has been taken, neo-Chartalism contradicts the notion that modern banking money is endogenous, that is, a money conceived of as imposing itself on the State itself. However, the contradiction in question can be overcome, as Bell (2001) showed, re-examining the different types of debt. According to Bell, in modern banking systems debts are superimposed upon one another; the "monetary pyramid" is composed of several "storeys" differentiated by the degree of acceptability of the instruments involved: households can issue money (i.e. debts) that is less liquid than that issued by enterprises, which in turn is less liquid than that issued by banks, which in turn is less liquid that the ultimate and "decisive" money issued by the State ${ }^{17}$. There is thus a plural nature of debts and a plurality of moneys, but their homogenisation is ensured by a hierarchical order of banks.

Thus the tricky articulation of private and public currencies, and the complex relationships between them feed into the debate between post-Keynesians and neo-Chartalists. The apparition of parallel instruments of payment is mentioned, but it is not seen as a process of substitution taking place between financial assets. In actual fact, monetary plurality does indeed lurk here, but in the idea of a plurality of the sources and time frames of debts. It remains merely implicit. In generalising the interpretative grid based on the Western banking practices aimed at restoring the unity and unicity of money ${ }^{18}$, post-Keynesians and neoChartalists are not concerned by the deepening of an analysis of monetary plurality, except when it appears in the form of a factor in a payment-system crisis (today, the European crisis in public debt may focus thinking on the logic of the tax-drive-money nexus and its relationship to financial wariness of the homogenisation of the territorial plurality of debts issued in Euros) ${ }^{19}$.

\footnotetext{
${ }^{17}$ The 'simplified hierarchy' can be envisioned as a four-tiered debt pyramid, with the debt of households, firms, banks and the state each representing a single tier. (Bell, 2001, 159).

18 "In their efforts to systematise post-Keynesianism, writers such as Arestis, Davidson, Dow, Lavoie, Sawyer and Wray have made its object of analysis a generic, abstract 'economy' whose social substance is provided by modernity. This creates a post-Keynesian theory with the same appearance of formality and generality as neoclassical theory." (Danby, 2009, 1130)

19 "The divorce in the euro-zone between the nation state, which has retained its fiscal powers, and the money-
} 


\subsection{Marx and beyond}

The Marxist theory of money as a commodity expressing the commensurability of goods has over the past thirty years inspired conceptualisation of money as a general equivalent revealing tension between monetary unicity and plurality. A tension that is pretty obvious in studies setting the theoretical model on the general equivalent against empirical observation of the plurality of units of account among financial assets, and more so among means of payment. This plurality, however, does not invalidate the normative assumption of the existence of a general equivalent, as it is seen as a pathological condition.

The analyses in question start out from Marx's conceptualisation of the social function of money as a general equivalent. So, its definition has to be recalled before our analysis begins (5.2.1). Subsequently three types of analysis can be distinguished according to their mode of theorising the link between the existence of a diversity of forms of money and the postulate of a unique measure of value. The first approach does this by contesting the conception of money as the expression of the intrinsic value of commodities, and by redefining the general equivalent as the result of regulation (centralised or fragmented) of the diversity of private moneys (Aglietta \& Orléan, 1982) (5.2.2). A second approach reasserts on the contrary the anchoring of the general equivalent in the labour theory of value, basing its arguments on the wave of inflation in Brazil in the 1980s and interpreting the resultant plurality of units of account as a pathological fragmentation of the monetary system (SaadFilho \& Mollo, 1999) (5.2.3). The third approach, based on analysis of the plurality of units of account characteristic of the globalised financial system, shows that the unicity of the general equivalent appears merely as a contingent historical development if confronted with the monetary aspects of financial derivatives (Bryan \& Rafferty, 2007) (5.2.4).

\subsubsection{Marx's money}

Marx defines trade as a social relationship that founds the existence and role of money. "Money is born neither by convention, nor of the State. It is born quite naturally of trade and in trade, of which it is the product" (Marx, 1980, 102). Money is conceived as a general equivalent, the unit of account of the general form of value - the abstract work that is the common component embodied in the concrete work that produces goods. This is its "specific social function" (Marx, 1969, 79). Its genesis stems from a process that excludes from the world of goods one commodity. It is thus that money is created: to provide social measurement of the value of other goods.

Though money is unified as a general equivalent, providing a common language, the forms it takes in the circulation of goods are multiple. "In its function as a measure of values, money is used only as ideal money" (Marx, 1969, 105-106) by means of which "goods speak of themselves in their money-name." Money becomes truly real only as a result of sale and purchase, after having taken on a symbolical form as numeraire corresponding to its function as medium enabling commodities to circulate. The real form of money characterises money as a reserve of value that makes it a means of purchase (Marx, 1859, 90). Money as a measure of values can, besides this, have "substitutes" as an instrument of trade, such as notes or any other material thing used as a sign of value (Marx, 1969, 106) to fulfil its function. It must, however, be present in its material or metal form as the real equivalent of goods, or as itself a

creation powers which have been given to a federal institution, the European Central bank, is extremely risky" (Goodhart, 2005, 823). 
money commodity, in order to fulfil its function as a reserve and means of payment. It also takes on its metal embodiment when fulfilling its function as universal equivalent. The latter corresponds, in Marx's view, to international money as the absolute form of wealth. All of this being the case, all monetary forms are backed by the general equivalent. This also holds for credit money, which Marx deals with in Book III, Volume II of Capital, characterising the specificity of money in the capitalist mode of production. The general equivalent then takes on the form of central money, ensuring the convertibility of private moneys.

In Marx's theory, there is thus no possibility of tension between plurality of moneys and unicity of the unit of account, because the functional forms of money are all interdependent. Money is indeed a social recognition of the unit of account that is expressed in its function as reserve, by means of which its social power becomes the private power of individuals.

\subsubsection{Strong plurality based on centralised or fractional regulation}

Aglietta \& Orléan $(1982,2002)$ have re-founded Marx's analysis of the genesis of money, rejecting the hypothesis that a substantial value (in terms of utility or labour) exists prior to market relationships. They replace this with a hypothesis developed by the anthropologist René Girard (1977): that of mimetic rivalry. The genesis of money is assumed to be the result of a metamorphosis of the intrinsic violence of market relationships, with the commodity elected as general equivalent being unanimously accepted as the symbol of wealth. Market relationships are thus re-defined as rivalries that fissure and fragment the market order. In the beginning, each trading partner has by definition an interest in making his particular commodity the general equivalent. This rivalry is progressively absorbed into a mimetic polarisation of a single symbol of wealth that defines liquidity.

From this new viewpoint, the election of a commodity to serve as a measure of value is no longer seen as being deduced from trade, but rather as a construction of the social cohesion by the market, which makes emerge from its basic violence the election of a commodity that is coveted by all and elevating it to a position of sovereignty. With the capitalist production of commodities, this sovereignty takes the form of the authority of the central bank, the foundation of a hierarchical monetary system. The latter brings into play conflicting logics, either of centralisation by ensuring the convertibility of debt commitments into a base money, or of fractioning this convertibility on financial markets. The predominance of one or the other of these logics formats differing growth models by means of norms that regulate the development of private moneys, "by fostering the development of certain assets while forcibly constraining others" (Aglietta, Orléan, 1982, 86). Unanimity as to the unit of account is thus always provisional, as it implies arbitration by the monetary authority, which can favour debtors by opting for centralisation in applying a policy of refinancing that accommodates private liabilities, or on the other hand favour creditors, allowing the fractioning of the monetary organisation to take its course by granting creditors direct control over the management of debts.

According to this analysis, the plurality of issuers and the recognition by the community of merchants of liquidity as the undisputed representation of wealth are both crucial points, as unanimity is guaranteed by neither system. The value of debt claims is always potentially under threat (and consequently the source of a possible monetary crisis), either by inflation, when the predominant logic is that of centralisation, or by asphyxiating debtors when there is no longer an automatic guarantee inherent in the logic of fractioning. The tension between plurality and unicity of money is thus located at the very heart of a conception of money that sees the latter as a mediator between debts and liquidity. This 
tension is expressed in two particular forms, according to the type of hierarchy - banking or financial - prevailing in the creation of money. When the banking element is predominant, the tension is incorporated into the financial innovations that make it possible to circumvent limitations to the powers of creditors issuing private moneys that are convertible into the central money. When the financial element is dominant, the tension comes out in the mimetic logic of organised financial markets that base on the sovereign decision of the lender of last resort the sustainability of an evaluation of debt claims that ensures their liquidity.

The unicity of the unit of account is thus essential in both configurations, though its acceptance by society is no longer simply a logical deduction, as it was for Marx. It is the result of political arbitration - always provisional - of the trial of strength between debtors and creditors.

\subsubsection{Monetary plurality as a pathological loss of unity in the functions of money}

The wave of hyperinflation in Latin America would seem to provide a classic illustration of the current influence of Marx's definition of the general equivalent. Work by Saad-Filho \& Mollo (1999) on the Brazilian inflation defined as an expression of a distributive conflict revealed this influence clearly. The notion of general equivalent has been refined on the basis of a Marxist conception of the endogenous nature of the creation of money, which the authors articulate with the principle of unity of the functions of money. This proposition follows a contemporary marxist conception of inflation as the result of an extra money issue validating prices that are higher than exchange value (De Vroey, 1984; Brunhoff \& Cartelier, 1974; Brunhoff 1978; Itoh \& Lapavitzas, 1999). The Brazilian example shows how that inflation brakes the accumulation of capital as, by multiplying indexation mechanisms, it ruptures the links between prices and values. As a result social recognition of the general equivalent is no longer possible.

Non-mainstream studies explaining the rise of inflation as a result of conflicts in distribution in Brazil during the 1982-95 period have shown that the shock of the devaluations, which were decided as a means of producing the trade surpluses needed to cover the service of the debt, gave inflation a high degree of inertia, because it was constantly re-launched by indexation mechanisms that favoured holders of rents and recipients of profits, to the detriment of wage-earners (quoted by the authors: Bacha, 1982; Bresser Pereira \& Nakano, 1983; Mollo \& Silva, 1987). Saad-Filho \& Mollo show that mark-up's prices behaviour and anticipations stem from the issue of an extraordinary quantity of money linked, in this case, to the rise in interest base rates entailed by the institutionalisation, which went well beyond restrictive intentions, of the indexation of monetary assets. The restrictive effect of the interest rate was neutralised by the monetary swaps of obligatory reserves in Treasury bills. The central bank authorised this, and this in turn enabled banks to index their interest rates on high current-account holdings. The snowball effect of the resultant inflation entailed, according to the authors, that the unity of functions of the national currency had been destroyed as soon as pegging it to a dollar equivalent had ensured its function as a reserve of value. This index was subsequently recognized as the unit of account for durable goods that could serve as a means of reserve. The national currency ended up by losing its ability to fulfil its function as a means of circulation, and this undermined its social recognition as general equivalent. Distortions of relative prices blocked the process of accumulation, and first and foremost the level of interest rates guaranteeing the liquidity of the internal debt, to the detriment of investment, just as the international function of the currency was being undermined.

This analysis follows Marx's conception of money and likewise it converges with 
Aglietta \& Orléan's analysis of rivalry in the election of the unit of account. It exemplifies an extreme case of a monetary authority being forced to validate spiralling competitive indexations by means of a pathological inflationary mechanism of money creation pulled upwards by rising interest rates. This kind of monetary crisis is more specifically a crisis of the unicity of the unit of account. As in Marx, the unicity should be absolute as it guarantees the well-running interdependence of the functions of money. However, the analysis does not conceive the plurality of debt issuers as a decisive element of the relation between money and finance. The latter point can lead to redefine the general equivalent even more radically that Aglietta \& Orléan have done, through an examination of the financial markets-driven new monetary stage of capitalism.

\subsubsection{Plurality of units of account in specifically capitalist money}

Bryan \& Rafferty (BR) hypothesise that financial derivatives (FD) constitute a new form of global money, driven by competition as "their specific capacity as commodity money is to be self-transmutable, for this is the basis of competitive commensuration" (BR, 2007, 153). This fact gives the FD a monetary character that has two features: derivatives "through options and futures, establish pricing relationships that 'bind' the future to the present and one place to another [...] especially through swaps, [and] establish pricing relationships that readily convert between ['commensurate'] different forms of asset" (BR, 2007, 140). These empirical observations, in the authors' view, call for renewal of monetary theory so as to take account of this monetary function that the dynamics of capitalism have conferred on FD. They feel that the Marxist concept of money provides the only framework in which this would be possible. To theorise the function of commensurability of different types of capital that is fulfilled by FD, however, implies a generic concept of money that envelopes the multiplicity of monies of account, and this in turn entails an abandon the principle of the unicity of a general equivalent of value.

This distancing has a theoretical import. The meaning attributed to the social acceptance of money defines that which is common to its various particular forms. The authors stress this importance in view of the debate arising from the publication of Zelizer's arguments $(1994,2000)$ according to which money is the product of particular social practices, a view challenging all general theories founded on its economic properties. The authors come back to the Marxist argument invoked by Fine \& Lapavitzas (2000) that labour value is an abstraction that accounts for both the real foundation of money as a social relationship and the link between the various forms that money takes on. They set forward, however, the viewpoint that the nature of this abstraction has changed since the apparition of fiat moneys that have no intrinsic value. FD are a new form that should be treated as the outcome of a process of historical evolution of this abstraction, as Marx had already noted: an increase in the degree of abstraction of the intrinsic value of the monetary material in comparison with its exchange value (Marx, 1844). "The derivatives [...], when they are derived but separated from the properties of the underlying assets, are systematically abstracted from "particular goods" (Bryan \& Rafferty, 2007, 152). Thus they constitute a new form of money by means of which capital takes on the attributes of money, and money the attributes of capital. The role of money as facilitator of capitalist competition is thus doubled by the fact that the value of the money commodity itself ends up by being determined directly by competition. Its new capacity for abstraction renders values commensurable over and above the differences in space and time (synthesised concretely by differences in rates of interest and exchange in cash and forward exchange transactions). In this marxian conception of money, the unicity of the unit of account is merely historically contingent. The new phase 
in the evolution of the money/capital relationship implied by the derivatives innovations is characterized by competing units of account to fixing capital value and consequently a plurality of means of payment.

To conclude about the tension between monetary unicity and plurality revealed by these recent revisions of the concept of general equivalent, we remark in the first place that the inflationary treasury bills issued in Brazil during the 1982-94 period played, like the today's FD, the role of a "concrete universal form of monetary value" (Bryan \& Rafferty, $2007,153)$. These authors also point out that their study does not take up the question on the future of FD, which manifestly constitute a form of money whose stability is under question. The idea of a new kind of general equivalent that is somehow also plural and variable would then be a mere paradox. A recourse to oxymoron of this sort hides a tension between monetary unicity and plurality that appears to be as decisive for the Marxist research programme as the effort to conceptualise a purely market-based money in the liberal programme that stretches from Hayek to the financial approach we witness today. Approaches starting out from Marx, however, postulate a relationship between the market and the monetary expression of value that are the symmetrical opposite of the liberal one. The necessity of a unique unit of account of value involves the State (supposing that FD are a contingent non-sustainable monetary form), as election (i.e. social recognition) of the unit constitutes a properly monetary solution to the distributive conflict. Only Aglietta \& Orléan's analysis recognises this explicitly, from a position beyond Marxism.

\section{Conclusion: a typology of combinations of monetary unicity and plurality}

From a multidimensional definition of monetary plurality, understood as a plurality of means of payment or media of exchange, and also a plurality of units of account, standards of value or numeraires, this article has set out to examine each theoretical approach in its appropriate analytical context. Our examination of contemporary theories of money has revealed that there is a variety of situations involving plurality and unicity. We can now synthesise this in a typology.

As in economic theory money is constructed on the basis of the two functions of account and payment, unicity and plurality should not be diametrically opposed. A plurality of means of payment is not incompatible with unicity of the unit of account. The two functions should be thought out in combinations of configurations that are more or less completely plural or unique (Table 2 ).

To start with, several forms of plurality can be distinguished by degree of intensity. The decisive criterion determining the "strength" of plurality is in particular the degree of centralisation involved in the issuing of means of payment. Plurality depends thus to the way in which the diversity of means of payments is homogenised through the monetary system under the umbrella of the unit of account.

Today national monetary systems (see the grey column of Table 2) articulate in principle the link between the unicity of the unit of account (the State establishes its sovereignty in monetary matters by setting the unit of account to be used by public and private economic agents) and the plurality of means of payment (by authorising the central bank and a variable number of commercial banks to issue money). This plurality of means of payment is organised centrally, through the setting up of a guarantee on the convertibility at 
par of bank moneys in relation to one another and to the base money issued by the central bank. This guarantee is so strong that economic agents tend to see no difference between the forms of money concerned. The only differences that may crop up between the various issuers concern the interest rates at which the latter refinance. We will call this canonical configuration weak plurality: the system is unified, homogenised, hierarchical, but it is built on a plurality of means of payment.

When there is no such guarantee of convertibility at par, variable premiums and agios can be applied by economic agents in order to convert the particular bank money into the money of whatever other bank is involved, in view of their perception of the risks involved and also of the costs of e.g. the relevant logistics. In this case, the plurality of means of payment is made commensurable by using a common unit of account without, however, resulting in a system that makes all means of payment equivalent. In this case we can speak of medium plurality.

There is thus a whole series of possible configurations. The range extends from the theoretical configuration of the unique issuer at one extremity (no plurality; the Chicago Plan draws close to this, as do those post-Walrasian models that forego the possibility of several moneys; see our section 4), to the case of an unregulated plurality of issuers together with a plurality of units of account (strong plurality) at the other end of the scale. In between there are intermediate forms such as weak plurality (today's national monetary systems in their ideal form) and medium plurality (means of payment issued by various authorities are not rendered equivalent by a guarantee of convertibility at par into the unit of account).

As unicity is not the exact inverse image of plurality, an additional gradation has to be used to take account of the "strength" of the unicity. The criterion of this is the degree of unification of units of account. But this degree also depends on the way in which the diversity of means of payment is articulated to the unit of account and homogenised by this relationship. In economic theory, the "numeraire" is unique by definition, whereas in each national framework today, the country's unit of account is also unique by definition, as is the sovereign power that defines it. Plurality of units of account is thus by no means evident. Bearing this in mind, the gradation runs from strong unicity to no unicity, with in between weak unicity. At one extremity unicity is nil when it is based on an unorganised set of competing units of account: such is Hayek's system (section 3). Almost at the other extreme, unicity is strong when plurality is confined to issuers of means of payment or when there is only one. A weak form of unicity may cover those of the theories that conceive an organised or hierarchised plurality of units of account.

Table 2 presents an overview of possible configurations associating units of account and means of payment, positioning the economic theories of money examined in this article in their treatment of monetary unicity and plurality. 
Table 2 - Range of configurations of unicity and plurality

\begin{tabular}{|c|c|c|c|c|c|}
\hline \multicolumn{2}{|r|}{$\begin{array}{c}\text { ABSOLUTE } \\
\text { UNICITY }\end{array}$} & & & 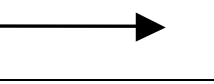 & $\begin{array}{l}\text { ABSOLUTE } \\
\text { PLURALITY }\end{array}$ \\
\hline $\begin{array}{l}\text { Degree of } \\
\text { unicity }\end{array}$ & \multicolumn{3}{|c|}{ Strong unicity } & Weak unicity & No unicity \\
\hline $\begin{array}{l}\text { Unit of } \\
\text { account }\end{array}$ & \multicolumn{3}{|c|}{ Unique } & $\begin{array}{l}\text { Hierarchised } \\
\text { plurality }\end{array}$ & $\begin{array}{l}\text { Competitive } \\
\text { plurality }\end{array}$ \\
\hline $\begin{array}{l}\text { Degree of } \\
\text { plurality }\end{array}$ & No Plurality & Weak plurality & $\begin{array}{l}\text { Medium } \\
\text { plurality }\end{array}$ & \multicolumn{2}{|c|}{ Strong plurality } \\
\hline $\begin{array}{l}\text { Issuers of } \\
\text { means of } \\
\text { payment }\end{array}$ & Unique & $\begin{array}{c}\text { Plurality ; guarantee } \\
\text { of convertibility at } \\
\text { par }\end{array}$ & $\begin{array}{c}\text { Plurality ; no } \\
\text { guarantee of } \\
\text { convertibility at } \\
\text { par }\end{array}$ & \multicolumn{2}{|c|}{ Unregulated plurality } \\
\hline
\end{tabular}

Theories studied:

\begin{tabular}{|c|c|c|c|c|c|}
\hline \multirow[t]{2}{*}{ Section 2} & & & \multicolumn{3}{|c|}{ New monetary economics: } \\
\hline & & & YGS model & Hall & $\begin{array}{l}\text { Cowen \& } \\
\text { Kroszner }\end{array}$ \\
\hline \multirow[t]{2}{*}{ Section 3} & & \multicolumn{4}{|c|}{ Neo-Mengerians: } \\
\hline & & \multicolumn{2}{|c|}{ Free banking } & \multicolumn{2}{|c|}{ Result $\leftarrow$ Hayek $\rightarrow$ Departure } \\
\hline \multirow[t]{2}{*}{ Section 4} & \multicolumn{4}{|c|}{ Theories of money in general equilibrium: } & \\
\hline & $\begin{array}{c}\text { Monetary } \\
\text { Walrasianism (in } \\
\text { general) \& } \\
\text { Chicago Plan } \\
\end{array}$ & & $\begin{array}{l}\text { Plurality as ce } \\
\text { monetary W }\end{array}$ & $\begin{array}{l}\text { ceived by } \\
\text { asianism }\end{array}$ & \\
\hline \multirow[t]{5}{*}{ Section 5} & \multicolumn{2}{|c|}{ Neo-Chartalists: } & & & \\
\hline & Lerner & Knapp & & & \\
\hline & & \multicolumn{2}{|c|}{ Post-Keynesianism: } & & \\
\hline & & Cartalists & $\begin{array}{c}\text { Minsky (plurality } \\
\text { of debts) }\end{array}$ & & \\
\hline & & \multicolumn{4}{|c|}{ Contemporary Marxism: } \\
\hline
\end{tabular}

\section{References}

Aglietta Michel \& Orléan André, (1982), La violence de la monnaie, Paris, Presses Universitaires de France.

Aglietta Michel \& Orléan André, (2002), La monnaie entre violence et confiance, Paris, Odile Jacob.

Allais Maurice, 1975, «Le Concept de Monnaie, la Création de Monnaie et de Pouvoir d'Achat par le Mécanisme de Crédit et ses Implications ", in P. Coulbois (Ed.), Essais en l'Honneur de Jean Marchal, tome ii : La Monnaie, Paris, Cujas, pp.106-145.

Allais Maurice, 1993, «Les Conditions Monétaires d'une Economie de Marchés », Revue d'Economie Politique, vol.103, $\mathrm{n}^{\circ} 3$, mai-juin.

Arestis Philip \& Glickman Murray, 2002, "Financial crisis in Southeast Asia: Dispelling illusion the Minskyan way », Cambridge Journal of Economics; March 2002; 26, 2, pp. 237-260.

Bacha, Edmar L (1982), "Inflação: Uma agenda não monetarista" in M.C. Tavares \& M.D. David (eds.) A economia Política da Crise. Rio de Janeiro: Vozes,

Barro Robert, 1979, « Money and the Price Level under the Gold Standard », Economic Journal, 89, pp. 13-33. 
Barro Robert, Plosser Charles I., 1983, “Alternative monetary standards”, Journal of Monetary Economics, 12(1), pp. 1197.

Baye Michael R., De Grauwe Paul \& De Vries Casper G., 1993, « An Oligopoly Model of Free Banking : Theory and Tests », De Economist, vol.141, n4, pp.497-514.

Bell, S., 2001, "The role of the state and the hierarchy of money", Cambridge Journal of Economics, 25, pp.149-163

Benetti Carlo, 2001, "Monnaie, choix individuels et frictions", Cahiers d'économie politique, n³9, pp. 89-106.

Black Fischer, 1972, “Active and Passive monetary Policy in a neo-classical model”, Journal of Finance, 27(4), pp. 801814.

Black Fischer, 1974, "Uniqueness of the Price Level in Monetary Growth Models with Rational Expectations", Journal of Economic Theory, 7, pp. 53-65.

Black Fischer, 1978, "Global Monetarism in a World of National Currencies", Columbia Journal of World Business, Spring, pp. 27-32.

Black Fischer, 1981, “A Gold Standard with Double Feedback and Near-Zero Reserves », unpublished MIT. Reprinted in Business Cycles and Equilibrium. New. York: Basil Blackwell Press, 1987, pp. 129-134.

Black Fisher, 1970, « Banking and the Interest Rates in a World without Money », Journal of Bank Research, Autumn, pp.9-20.

Bresser Pereira, Luis C.., \& Nakano, Yoshiaki., (1985). "The theoy of Inertial Inflation: the Founadation of Economic Reform in Brazil and Argentina", Boulder: Lyenne Rienner.

Bryan Dick \& Rafferty Michael, (2007), "Financial derivatives and the theory of money", Economy and Society, 36 (1), pp. 134-158

Bryant John, 1980, “The competitive Provision of Fiat Money”, Staff Report \#48, Federal Reserve Bank of Minneapolis.

Campbell, M., 2005, "Marx's explanation of Money's Functions: Overturning the Quantity Theory", in Moseley, F., Marx's Theory of Money, Modern Appraisals, New York: Palgrave Mac Millan, pp. 143-159

Cartelier Jean (2001), "Monnaie et marché. Un point de vue critique sur les modèles de prospection", Revue économique, 52, no 5, pp. 993-1011.

Cartelier, J., de Brunhoff, S., 1974, «Une analyse marxiste de l'inflation », in Chronique sociale de France, 1974, repris dans Les rapports d'argent, de Brunhoff, PUG, pp.119-135.

Chang Roberto (1994), "Endogenous Currency Substitution, Inflationary Finance, and Welfare", Journal of Money, Credit and Banking, 26, no 4, pp. 903-916.

Clower Robert (1967), "A reconsideration of the microfoundations of monetary theory", Western Economic Journal, 6, no 4, pp. 1-8.

Cowen Tyler et Kroszner Randall, 1987, «The Development of the New Monetary Economics », Journal of Political Economy, vol.95, n³1, pp.567-590.

Cowen Tyler et Kroszner Randall, 1994, Explorations in the New Monetary Economics, Oxford, Blackwell.

Danby Colin, 2009, "Post-Keynesianism without modernity", Cambridge Journal of Economics 33, pp.1119-1133

Davidson, P., 1972, Money and the Real World, Mc Millan, London, 1978.

De Brunhoff, S. (2005), "Marx's Contribution to the Search for a Theory of Money", in Moseley, F., Marx's Theory of Money, Modern Appraisals, New York: Palgrave Mac Millan, pp. 209-221.

De Brunhoff, S., 1978, The state, capital and economic policy, London, Pluto Press.

De Vroey Michel, (1984), "Inflation: A Non Monetarist Moneray Interpretation", Cambridge Journal of Economics, 8, pp. 381-399

Diamond Peter A. (1965), "National debt in a neoclassical growth model", American Economic Review, 55, no 5, part I, pp. 1126-1150.

Dorn James A., 1989, "Introduction. Alternatives to Government Fiat Money”, Cato Journal, 9(2), pp. $277-294$.

Dow Sheila, 1996, "Horizontalism: A Critique," Cambridge Journal of Economics, Oxford University Press, vol. 20(4), pages 497-508, July

Dowd Kevin (Ed.), 1992, The Experience of Free Banking, Londres, Routledge.

Dowd Kevin, 1994, “A Proposal to End Inflation”, Economic Journal, 104(425), pp. 828-840.

Duca John V. and Van Hoose David D. (2004), "Recent developments in understanding the demand for money", Journal of Economics and Business, 56, no 4, pp. 247-272.

Fama Eugene F. [1980], « Banking in the Theory of Finance », Journal of Monetary Economics, vol.6, pp.39-57.

Fama Eugene, 1983, "Financial Intermediation and Price Level Control”, Journal of Monetary Economics, 12, pp. 7-28.

Fama Eugene, 1985, "What's different about banks", Journal of Monetary Economics, 15, pp. 29-39.

Fine Ben and Lapavitzas C . (2000), "Markets and Money in Social Theory: what Role for Economics",Economy and Society, 29 (3), pp. 357-82

Fisher Irving, 1935, 100\% Money, Adelphi Publication, New York.

Fisher, Irving (1920). Stabilizing the Dollar. New York: Macmillan.

Friedman Milton, 1959, A Program for Monetary Stability, New York, Fordham University Press.

Friedman Milton, 1969, The Optimum Quantity of Money and Other Essays. Chicago: Aldine.

Friedman Milton, 1984, "Financial Futures Markets and Tabular Standards", Journal of Political Economy, 92(1), pp. 
$165-167$.

Girard R. (1977), Violence and the sacred, The Johns Hopkins University Press, Baltimore, Maryland, London

Gnos Claude, Rochon, Louis-Philippe, 2002 "Money Creation and the State : A Critical Assessment of Chartalism," International Journal of Political Economy, vol. 32(3), pages 41-57

Gomez-Betancourt Rebeca \& de Boyer des Roches Jérôme, 2013, « Origins and Developments of Fisher Compensated Dollar Plan », European Journal of the History of Economic Thought, 20(2), April, pp. 261-283.

Goodhart Charles, 1989, "Has Moore Become too Horizontal?", Journal of Post Keynesian Economics, Vol. 12, No. 1, pp. 29-34

Goodhart, C.A.E., 2005, « What is the essence of money ? », Cambridge Journal of Economics, 29, pp.817-825.

Greenfield Robert L., and Yeager Leland B., 1983, “A laisser-Faire approach to Monetary Stability”, Journal of Money, Credit and Banking, 15(3), pp. 302-315.

Greenfield Robert L., Woolsey William W. and Yeager Leland B., 1995, “ Is Indirect Convertibility Impossible? Comment", Journal of Money, Credit and Banking, 27(1), February, pp. 293-297.

Hahn, F.M., 1965, "On some problems of proving the existence of an equilibrium in a monetary economy", in: F.H. Hahn and F. Brechling, The theory of interest rates (Macmillan, London).

Hall Robert E., 1981. The Government and the Monetary Unit, Working paper \#159, NBER, December.

Hall Robert E., 1982a, "Monetary Trends in The United States and The United Kingdom: A Review From the Perspective of New Developments in Monetary Economics", Journal of Economic Literature, 20(4), p. 1552-1556.

Hall Robert E., 1982b, "Explorations in the Gold Standard and Related Policies for Stabilizing the Dollar", in R H. Hall (ed.), Inflation, NBER, chap. 4, pp. 111-122.

Hall Robert E., 1983, « Optimal Fiduciary Monetary Systems », Journal of Monetary Economics, vol.12, pp.33-50.

Hall Robert E., 1992, “A Free-Market Policy to Stabilize the Purchasing Power of the Dollar”, in Barry N. Siegel (ed.), Money in Crisis. The Federal Reserve, the Economy, and Monetary Reform, Cambridge, MA., Harper and Row Pub., chap. 12, pp. 303-321.

Hall Robert E., 1997, “Irving Fisher's Self-Stabilizing Money”, American Economic Review, 87(2), p. 436-438.

Hall Robert E., 2002, "Controlling the Price Level”, Contribution to Macroeconomics, 2(1), p. 1-17.

Hayek Friedrich A., 1979, “Toward a Free Market Monetary System”, Journal of libertarian Studies, 3(1), pp. 1-8.

Hayek, Friedrich von, 1978, Denationalisation of Money. The Argument Refined. An Analysis of the Theory and Practice of Concurrent Currencies [1976]. 2e édition. Préface Arthur Seldon. London : IEA (Hobart Paper Special 70). $144 \mathrm{p}$.

Hein Eckhard 2004, "Money, credit and the interest rate in Marx's economics on the similarities of Marx's monetary analysis to post-keynesian economics", International papers in political economy, WSI in der Hans Boeckler stiftung, Vol. 11, 2

Hellwig, Martin (1993), « The challenge of monetary theory », European Economic Review, vol.37, n²-3, pp. $215-242$.

Hicks John, 1935, “A Suggestion for Simplifying the Theory of Money”, Economica, new series, Vol. 2, n 5, pp. 1-19.

Hoover Kevin D., 1988, "Money, Prices and Finance in the New Monetary Economics", Oxford Economic Papers. New Series, 40(1), pp. 150-167.

Itoh Makato and Lapavitzas Costas, 1999, Political Economy of Money and Finance, Macmillan. London, England.

Iwai Katsuhito (1988), "The evolution of money. A search-theoretic foundation of monetary economics", CARESS Working paper, Philadelphia, No 88-03, $71 \mathrm{p}$.

Iwai Katsuhito (1996), "The boostrap theory of money: A search-theoretic foundation of monetary economics", Structural Change and Economic Dynamics, 7, no 4, pp. 451-477.

Jevons William Stanley (1875), Money and the Mechanism of Exchange, London: H. S. King, 349 p.

Kaldor, N. 1960. "The Radcliffe Report", Review of Economics and Statistics, 60:1, pp.27-38.

Kaldor, N. 1982. The Scourge of Monetarism. New York: Oxford University Press

Kareken John, and Wallace Neil, 1978, “International Monetary Reform”, Federal Reserve Bank of Mineapolis Quaterly Review, 2 (Summer), pp. 2-7.

Kareken John, and Wallace Neil, 1981, "On the Indeterminacy of Equilibrium Exchange Rates", The Quarterly Journal of Economics, 96, no 2, pp. 207-222.

Kareken John, and Wallace Neil, eds., 1980, Models of Monetary Economies, Minneapolis: Federal Reserve Bank of Minneapolis, vii $+313 \mathrm{p}$.

Keynes, J.M., 1930, A Treatise on Money : the Pure Theory of Money, 1930 (I), in The Collected Writings of John Maynard Keynes, MacMillan, Londres, T.V, 1971

Keynes, J.M.,1937, “Alternative theories of the rate of interest”, Economic Journal, 1937, in: Collected Writings, vol. 14, pp. 201-215.

Kiyotaki Nobuhiro and Wright Randall (1991), "A Contribution to the Pure Theory of Money", Journal of Economic Theory, 53, no, pp. 215-235.

Kiyotaki Nobuhiro and Wright Randall (1993), "A Search-Theoretic Approach to Monetary Economics", The American Economic Review, 83, no 1, pp. 63-77.

Kiyotaki Nohiburo and Wright Randall (1989), "On Money as a Medium of Exchange", Journal of Political Economy, 
97, no 4, pp. 927-954.

Klein Benjamin, 1974, “The Competitive Supply of Money”, Journal of Money, Credit and Banking, 6(4), 423-453.

Knapp, G.F. (1924), The State Theory of Money (1905), Londres, Macmillan.

Kocherlakota Narayana and Krueger Thomas (1999), "A Signaling Model of Multiple Currencies", Review of Economic Dynamics, 2, no 1, pp. 231-244.

Kocherlakota Narayana R. (1998), "Money Is Memory", Journal of Economic Theory, 81, no 2, pp. $232-251$.

Lau, J.Y.F., and J. Smithin, "The role of money in capitalism", International Journal of Political Economy 32, 3, Fall

Lavoie, Marc. (1992), Foundations of post-keynesian economic analysis, Edward Elgar.

Lavoie, Marc. 1984, "The Endogenous Flow of Credit and the Post Keynesian Theory." Journal of Economic Issues, 18 (3), 771-797. In M. Mussella, C. Panico (éd.), The Money Supply in the Economic Process. A Post-keynesian Perspective, Aldershot, Edward Elgar, pp. 385-411.

Lavoie, Marc. 1987, “Monnaie et production: une synthèse de la théorie du circuit”. Economies et Sociétés, 9 (4), pp.64101

Le Maux Laurent, 2004, "L'émergence d'une banque supérieure sous le régime de la liberté bancaire », Recherches Economiques de Louvain, vol.70, n², pp.193-221.

Le Maux Laurent, 2007, "Une théorie de la marque monétaire. L’impossibilité de la dénationalisation de la monnaie", Revue économique, 58(5), pp. 985-1009.

Lerner, A.P., 1947, "Money as a creature of the state", American Economic Review, 37, 2, pp.312-317.

Likitkysomboon, P. (2005), "Marx's Anti-Quantity Theory of Money: A Critical Evaluation”, in Moseley, F., Marx's Theory of Money, Modern Appraisals, New York: Palgrave Mac Millan, pp.160-175

Lucas Robert E. and Stokey Nancy L. (1983), "Optimal fiscal and monetary policy in an economy without capital", Journal of Monetary Economics, 12, no, pp. 55-93.

Lucas Robert E., 1972, "Expectations and the Neutrality of Money”, Journal of Economic Theory, 4, pp. 103-124.

Lucas Robert E., 1995, “Monetary Neutrality. Prize Lecture”, Economic Sciences, december 7, pp. 491-513.

Marx Karl (1859), A Contribution to the Critique of Political Economy, New York, International Publishers, 1970.

Marx Karl, (1844), "Notebook comments on James Mill, Elements of Political Economy", trans. Clemens Dutt for Collected Works, Available at: <www.marxists.org/archive/marx/works/1844-mil/index.htm>

Marx, Le capital, 1969.

McCallum Bennett T. (1983), "The role of overlapping-generations models in monetary economics", Carnegie-Rochester Conference Series on Public Policy, 18, no, pp. 9-44.

McCallum Bennett T., 2010, "Issues concerning nonpecuniary yield of Money”, Cato Journal 30(3), pp. 439-449.

Mehrling Perry, 1998, "The Money Muddle: The Transformation of American Monetary Thought, 1920-1970 in Morgan Mary S. and Rutherford Malcolm (eds), From Interwar Pluralism to Postwar Neoclassicism, edited by. History of Political Economy, 30. Durham, North Carolina: Duke University Press. pp. 293-306.

Mehrling Perry, 2000, Understanding Fisher Black, Barnard College, Columbia University, mimeo.

Meltzer Allan H., 1989, “Eliminating Monetary Disturbances”, Cato Journal, 9(2), pp. 423-428.

Menger Karl (1892), "On the origin of money", Economic Journal, 2, no 6, pp. 239-255.

Minsky, Hyman P., 1957, "Central Banking and Money Market Changes”, The Quarterly Journal of Economics, Vol. 71, No. 2, pp. 171-187

Minsky, Hyman P., 1986. Stabilizing an Unstable Economy. New Haven, CT: Yale University Press.

Mises (von) Ludwig (1949), Human Action, London, William Hodge.

Mollo, Maria .L.R. \& Silva, Maria.L.F. (1987). "Inflação e Conflito Distributivo: Um Jogo de Cartas Marcadas," Humanidades, 14, Aug-Oct.

Moore, B.J., 1988, Horizontalists and Verticalists: the Macro-economics of Credit Money, Cambridge University Press, Cambridge.

Moore, Basil J., 1991, “Has the Demand for Money Been Mislaid?”, Journal of Post Keynesian Economics, Vol. 14, No. 1, pp. $125-133$

Mundell Robert (1961), "A Theory of Optimum Currency Areas", American Economic Review, 51, no 4, pp. $657-665$.

Niggle, C. J. 1991, “The Endogenous Money Supply Theory: An Institutionalist Appraisal”, Journal of Economic Issues, Vol. 25, 1, pp. 137-151

O’Driscoll Gerald P., 1985, “Money: Menger's evolutionary theory”, Research Paper $n^{\circ} 8508$, Federal Reserve Bank of Dallas.

Orléan André (2009), "La sociologie économique de la monnaie", in: Philippe Steiner and François Vatin (Eds.), Traité de sociologie économique, Paris: PUF, pp. 209-246.

Panagopoulos Y., Spiliotis A., 2008, “Alternative money theories: a G7 testing”, Journal of Post Keynesian Economics, Vol. 30, 4, pp.601-622

Patinkin, Donald, 1956, Money, interest and Prices, Rown Peterson: Evanston.

Piégay, Pierre, Rochon, Louis-Philippe, 2000, Politiques monétaires post-keynésiennes, Economica, Paris

Rochon, L.-P. 1999, Credit, Money and Production. Cheltenham, UK: Edward Elgar,

Rochon, Louis-Philippe, Vernengo, Matias, 2003, "State Money and the Real World: Or Chartalism and Its Discontents", 
Journal of Post Keynesian Economics, Vol. 26, No. 1, pp. 57-67

Rothbard Murray, 1962, "The case for a 100 Percent Gold Dollar », in L. Yeager ed., In Search of a Monetary Constitution, Cambridge (Mass.), Harvard University Press.

Rousseas, S. 1960. "Velocity Changes and the Effectiveness of Monetary Policy", Review of Economics and Statistics, 42 $: 1, \mathrm{pp} .46-58$

Saad-Filho Alfredo and Mollo Maria de Lourdes R., (1999), "Inflation, Currency and Stabilization in Brazil: a Political Economy Analysis", Research Papers in International Business, $\mathrm{n}^{\circ} 17$,

Samuelson Paul A. (1958), "An exact consumption-loan model of interest with or without the social contrivance of money", Journal of Political Economy, 66, no 6, pp. 467-482.

Schnadt, N., and Whittaker, J. (1993), "Inflation-Proof Currency? The Feasibility of Variable Commodity Standards." Journal of Money, Credit, and Banking 25 (May): 214-21.

Scialom, Laurence, 1995, "Les modèles de paiement concurrentiels. Éléments d'analyse critique », Revue économique, vol. $46, \mathrm{n}^{\circ} 1$, janvier, pp. 35-55.

Selgin George A. and White Lawrence H. (1994), "How Would the Invisible Hand Handle Money ?" Journal of Economic Literature, XXXII, n4, pp. 1718-1749.

Selgin George A., 1988, The Theory of Free Banking, Totowa, N.J., Rowman \& Littlefield.

Selgin, George A., 2003, "Adaptive Learning and the Transition to Fiat Money”, Economic Journal, vol. 113, No. 484, pp. 147-165.

Shiller Robert J., 1998, "Designing Indexed Units of Account”, Cowles Foundation Discussion Paper $n^{\circ} 1179$, Yale University.

Shiller Robert J., 2002, "Indexed Units of Account: Theory and Assessment of Historical Experience”, I, Lefort F. \& Schmidt-Hebbel K. (eds), Indexation, Inflation, nda Monetary Policy, Santiago: Central Bank of Chile.

Simons Henry C., 1934, A Positive Program for Laisser-faire, Public Policy Pamphlet, ${ }^{\circ} 15$, University of Chicago Press, dans Economic Policy for a Free Society, The University of Chicago Press, 1948.

Sturzenegger Federico N. (1992), "Inflation and Social Welfare in a Model With Endogenous Financial Adaptation", UCLA Economics Working Papers, Los Angeles, No 658, 26 p.

Sumner Scott, 1989, «Using Futures Instrument Prices to Target Nominal Income », Bulletin of Economic Research, 41(2), pp. 157-162.

Sumner Scott, 1990, "The Forerunners of "New Monetary Economics" Proposals to Stabilize the Unit of Account: Note $»$, Journal of Money, Credit and Banking, 22(1), pp. 109-118.

Thompson Earl A., 1974, « The Theory of Money and Income consistent with Orthodox Value Theory », in P. Samuelson and G. Harwich (eds), Trade, Stability and Macroeconomics. Essays in Honour of Lloyd A. Meltzer, New York, Academic Press, pp. 427-453.

Uribe Martín (1997), "Hysteresis in a simple model of currency substitution", Journal of Monetary Economics, 40, no 1, pp. 185-202.

Vaubel Roland, 1984, “The Government's Money Monopoliy: Externalities or Natural Monopoly”, Kyklos, 37(1), pp. 2758.

Vaubel Roland, 1986, “Currency Competition versus Governmental Money Monopolies”, Cato Journal, 5(3), pp. 927942.

Wallace Neil (1977), "Why the Fed Should Consider Holding M0 Constant", Federal Reserve Bank of Minneapolis Quarterly Review, Summer, pp. 2-10.

Wallace Neil, 1979, "Why Markets in Foreign Exchange Are Different From Other markets", Federal Reserve Bank of Mineapolis Quaterly Review, 3 (Fall), pp. 1-7.

Wallace Neil, 1980, "The overlapping Generations Model of Fiat Money", in Kareken John, and Wallace Neil (eds), Models of Monetary Economics, Federal Reserve Bank of Mineapolis, pp. 49-82.

Wallace Neil, 1983, "A Legal Restrictions Theory of the Demand for "Money" and the Role of Monetary Policy", Federal Reserve Bank of Mineapolis Quaterly Review, (winter), pp. 1-7.

White Lawrence H., 1984a, "Competitive Payments Systems and the Unit of Account", The American Economic Review, 74(4), pp. 699-712.

White Lawrence H., 1984b, Free Banking in Britain : Theory, Experience and Debate, 1800-1845, Cambridge University Press, Cambridge.

White Lawrence H., 1987, “Accounting for Non-Interest-bearing Currency: A critique of the Legal Restrictions Theory of Money", Journal of Money, Credit and Banking, 19(4), pp. 448-456.

White Lawrence H., 1989, “What kind of Monetary Institutions Would a Free Market Deliver?”, Cato Journal, 9(2), pp. 367-391.

Woolsey W. William, 1992, “The Search for Macroeconomic Stability: Comment on Sumner”, Cato Journal, 12(2), pp. 475-485.

Woolsey W. William, 1994, «Stabilizing the Expected Price Level in a BFH Payments System », Contemporary Economic Policy, 12(2), pp. 46-54.

Wray, Randall, 1998, Understanding Modern Money: the Key toFull Employment and Price Stability, Edward Elgar, 
Cheltenham.

Wray, Randall, 2003, "L’approche post-keynésienne de la monnaie”, in Piégay, Rochon eds, pp.52-65

Yeager L. B., (1992) "Toward Forecast-Free Monetary Institutions." Cato Journal 12 (Spring-Summer): 53-73.

Yeager L.B., 1997, "Austrian Economics, Neoclassicism, and the market Test”, Journal of Economic Perspectives, 11 (4), pp. 153-165.

Yeager L.B., 2010, "Privatizing Money”, Cato Journal, Vol. 30, No. 3 (Fall 2010).

Yeager Leland B., \& Greenfield Robert L., 1989, “Can Monetary Disequilibrium Be Eliminated?”, Cato Journal, 9(2), pp. 405-421.

Yeager Leland, 1989, “A Competitive Payments System: Some Objections Considered”, Journal of Post Keynesian Economics, 11 (Spring), pp. 370-377.

Yeager Leland, 1994, "Mises and Hayek on Calculation and Knowledge", Review of Austrian Economics, 7(2), pp. 93109.

Yeager Leland, 1999, "Should Austrians Scorn General-Equilibrium Theory?", Review of Austrian Economics, 11, pp. 19-30.

Yeager, L. B. (1985) "Deregulation and Monetary Reform." American Economic Review Papers and Proceedings 75 (May): 103-07.ger

Yeager, L. B. (1983) "Stable Money and Free-Market Currencies." Cato Journal 3 (Fall): 305-26.

Yeager, L. B., 2001 "The Perils of Base Money", Review of Austrian Economics, 14(4), pp. 251-266.

Zelizer Viviana, (1994), The Social Meaning of Money, New York, Basic Books

Zelizer Viviana, (2000), "Fine Tuning the Zelizer View", Economy and Society, 34(4), pp. 584-8 